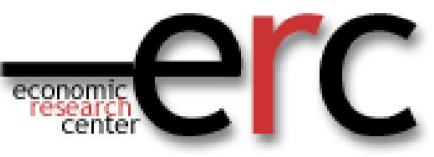

ERC Working Papers in Economics 09/03 October 2009

\title{
Hazard Analysis of Unemployment Duration by Gender in a Developing Country: The Case of Turkey
}

\author{
Aysit Tansel \\ Department of Economics \\ Middle East Technical University \\ Ankara 06531 Turkey \\ Email: atansel@metu.edu.tr \\ and \\ Institute for the Study of Labor (IZA) Bonn, Germany \\ Phone: +903122102057 \\ Fax: +90 3122107964 \\ E-mail: atansel@metu.edu.tr \\ H. Mehmet Taşçı \\ Department of Economics \\ Balıkesir University \\ 10200 Bandırma/Balıkesir \\ Phone: 90-555-718 7879 \\ E-mail:mtasci1@yahoo.com
}

\section{Economic Research Center}

Middle East Technical University

Ankara 06531 Turkey

www.erc.metu.edu.tr 


\title{
HAZARD ANALYSIS OF UNEMPLOYMENT DURATION \\ BY GENDER IN A DEVELOPING COUNTRY: \\ THE CASE OF TURKEY ${ }^{1}$
}

\author{
AYSIT TANSEL ${ }^{2}$ \\ Department of Economics \\ Middle East Technical University, \\ 06531 Ankara, TURKEY \\ and \\ Institute for Study of Labor (IZA) \\ Bonn, Germany \\ E-mail: atansel@metu.edu.tr \\ Telephone: 90-312-210 \\ 2057 \\ And \\ H. MEHMET TAŞÇI \\ Department of Econometrics \\ Balikesir University, \\ 10200 Bandirma/Balikesir, TURKEY \\ E-mail: mtasci1@yahoo.com \\ Telephone: 90-555-718 \\ 7879
}

Keywords: Unemployment Duration, Hazard Analysis, Gender, Turkey

JEL Classification: J64, C41, J16

Running Title: Unemployment Duration by Gender in Turkey.

\footnotetext{
1 This paper is based on H. Mehmet Taş̧̧'s PhD thesis (Taş̧1, 2005) prepared under the supervision of Aysit Tansel at the Department of Economics, Middle East Technical University. H. Mehmet Taşçı would like to thank Hakan Ercan, Abuzer Pınar, Yusuf Ziya Özcan and Cem Somel for their helpful comments on his Ph.D thesis. Thanks are also due to Șefik Yıldızeli and Ömer Demir past and current presidents of the Turkish Statistical Institute (TUIK), Nurgül Öğüt former vice-president and Enver Tastı director of the Labor Force Statistics Department of TUIK for their kind help in implementing this study. Earlier versions of this paper were presented at the ERC/METU International Conference in Economics VI, September 2002 in Ankara, Koç University in April 2004 in İstanbul, MENA Economies: Past Perspectives and Future Challenges Conference in May 2005 in Brussels, IZA/SOLE Transatlantic Meeting of Labor Economists in June 2005, Buch/Ammersee and Bilkent University in November 2005 in Ankara. Thanks are due to the conference participants, İnsan Tunalı and Sumru Altug for helpful comments on an earlier version of the paper. We would like to thank an anonymous referee of the LABOUR: Review of Labor Economics and Industrial Relations for helpful comments on the manuscript. Any errors are our own.

${ }^{2}$ Corresponding author.
} 


\begin{abstract}
:
There is little evidence on unemployment duration and its determinants in developing countries. This study is on the duration aspect of unemployment in a developing country, Turkey. We analyze the determinants of the probability of leaving unemployment for employment or the hazard rate. The effects of the personal and household characteristics and the local labor market conditions are examined. The analyses are carried out for men and women separately. The results indicate that the nature of unemployment in Turkey exhibits similarities to the unemployment in both the developed and the developing countries.
\end{abstract}




\section{Introduction}

Unemployment is one of the main challenges of the modern era in both the developed and developing countries. The costs of unemployment at the economic, social and individual levels are well documented in the literature. Further, there is also evidence that the economic, social and individual costs of unemployment are universal in developed and developing countries (Sabot, 1982). For instance, at the macroeconomic level, output loss due to unemployment is considered to be a problem central to all times and all countries. Furthermore, unemployment entails not only loss of output, but also non payment of taxes and social security premiums. Therefore, revenue loss to the government due to unemployment could be substantial (Reyher et al., 1979). Unemployment is considered to result in motivation and opportunity for crime and the positive correlation between unemployment and various forms of crime is widely investigated. While some evidence is inconclusive, recent studies reveal a positive effect of unemployment on crime. (Fajnzylber, et al., 1998; Gould et al., 2002; Burdett et al., 2004; Huang et al., 2004; Fougère et al., 2006).

At the individual level, a general agreement exists on the conception that unemployment deprives people not only from their livelihood but also from meaningful activity in their lives. Certain undesirable effects of unemployment experienced by the unemployed are delineated below. Unemployment is found to cause loss of self esteem (Goldsmith et al., 1996). The relation between suicide and unemployment is found to be more important than that between suicide and other 
socio-economic measures (Platt, 1984; Lewis and Sloggett, 1998). Further, it is widely observed that unemployment adversely affects mental health (Jackson and Warr, 1984; Darity Jr. and Goldsmith, 1996; Murphy and Athanasou, 1999) and good health spells (Cooper et al., 2007). An increasingly growing literature provides evidence on the adverse effect of unemployment on life satisfaction (Clark and Oswald, 1994; Frey and Stutzer, 2000; Eggers et al., 2006; Powdthavee, 2006). The duration of unemployment and its impact on the individual have been studied as well. Clark (2006) has found that the widely observed negative effect of unemployment on life satisfaction is mostly independent of unemployment duration. Long-term unemployment is believed to cause depreciation of human capital and erosion of work habits, which would affect subsequent wages. Arulampalan (2001) in the U.K., Knight and Li (2006) in urban China and Fitzenberger and Wilke (2007) in Germany revealed a significantly negative effect of unemployment duration on post unemployment wages. These observations indicate that unemployment is an important problem from both the individual and societal perspective. Therefore, analysis of unemployment duration focused on in this paper will contribute to our understanding of this problem from the individual, household and community perspectives.

However, differences are expected in the incidence and nature of unemployment in developed and developing countries, a situation which is largely due to the differences in labour laws, labour market structures and institutions in developed and developing countries. Some of the salient stylized facts, which are also 
relevant to Turkey as a developing country, are summarized below. Most developing country labour markets are segmented into formal and informal sectors while developed country labour markets exhibit a more uniform structure. The formal sector may be governed by employment protection legislation, permanent contracts, social security coverage, retirement and health benefits and minimum wage legislation similar to regulations existing in many developed country labour markets. On the other hand, formal regulations do not cover the informal sector. Trade unionization is observed to be lower in developing than in developed countries. Wide family support of the unemployed in developing countries is replaced by the unemployment insurance system in developed countries. High proportions of self employment and unpaid family work are other salient features of developing country labour markets in contrast to the widespread wage work in developed countries. Some developing countries have regulations that guarantee public sector employment for tertiary school graduates. Indeed, unlike the unemployment in developed countries, Udall and Sinclair (1982) proposed the 'luxury unemployment' hypothesis in developing countries. In general, unemployment in developing countries is mainly an urban problem and it is higher among the relatively well educated and first-time job seekers. Another aspect of unemployment observed in developing countries is queuing for a public sector or a formal sector job. Furthermore, evidence exists that unemployment in developing countries is a consequence of insufficient job creation as well as loss of employment during crisis periods. These and other aspects of unemployment in developing countries are highlighted by Hirschman (1982) in Malaysia, Glewwe (1989), Dickens and Lang (1996) and Rama (1999) in Sri Lanka, Rama (1998) in 
Tunisia, Manning and Junankar (1998) in Indonesia and Tenjo (1990) in Colombia. Analysis in this paper suggests that various aspects of unemployment in Turkey reflect similarities characteristic to both developing and developed countries.

The estimated official unemployment rate in Turkey was approximately 8 percent in the 1990s and 10.3 in 2005 (Table, 1). In 2005, this rate is 9.5 percent in Germany and France, 9.2 percent in Spain, and 4.5 percent in Switzerland. Unemployment figures in some transition countries are rather high, such as 16.4 percent in the Slovak Republic.(OECD, 2006). The highest unemployment rate observed for men (women) in the OECD countries in 2005, is 16.9 (19.4) percent for Poland and the lowest rate is 2.7 (2.7) percent for Iceland. The corresponding rates for men (women) in Turkey are 10.3 (10.3) percent, which are rather high compared to the OECD average of 6.5 (7.0) percent (OECD, 2006). The incidence of long-term unemployment (proportion of jobseekers for more than one year) among the prime aged (25-54) was highest in the Slovak Republic with 68 percent and Greece with 54 percent, and lowest in Mexico with 2.4 percent and Korea with 0.8 percent. For Turkey, the proportion of long-term unemployed individuals was 39 percent in 2005 (Table 1) which approximates the OECD average of 35 percent (OECD Database). It is generally agreed that the official unemployment rate understates the extent of the problem in Turkey (Özel and Mehran, 1992). Hence, a more realistic measure would be obtained by combining the unemployment and underemployment rates ${ }^{\mathrm{i}}$, which yields a combined figure of 13.9 percent for 2005. Rather high unemployment rates are observed for the young and educated. Various unemployment measures in Turkey will be discussed in Section 2. 
The above reasons are an indication that in Turkey unemployment remains to be a serious problem on the agenda of policymakers.

Although the incidence of unemployment was investigated in earlier studies, such as Şenses (1994), Bulutay (1995) and others, this study is the first to provide evidence on the duration aspect of unemployment in Turkey, a developing country. Studies analyzing unemployment duration have mainly focused on developed countries. A number of applications exist of the by now familiar reduced-form duration model framework in the OECD countries, including for example, van den Berg and van Ours (1999) for France, and Portugal and Addison (2003) for Portugal, and Carroll (2006) for Australia. Some recent studies concentrate on transition economies, such as Earle and Pauna (1996) on Romania, Foley (1997) and Grogan and van den Berg (2001) on Russia, Kupets (2006) on Ukraine and Lubyova and van Ours (1997) on the Slovak Republic. The little evidence that exists on unemployment duration and its determinants in developing countries is presented in the studies by Tunali and Assaad (1992) on Egypt, Serneels $(2001 ; 2007)$ and Dendir (2006) on Ethiopia, and Aranki and Daoud (2006) on Palestine.

This study highlights several aspects of unemployment. First, the transition from unemployment to full time wage employment is considered. Using individual level unemployment duration data derived from 2000 and 2001 surveys, the determinants of unemployment duration in a hazard function framework are provided. Personal, household and local labour market characteristics are used to explain unemployment 
durations. The questions addressed pertain to the way various characteristics affect the probability of a person to leave unemployment for employment, and how this probability varies with the duration in unemployment. Second, this study uses grouped duration methodology due to Kiefer (1988) and Sueyoshi (1995). This is the appropriate methodology when the duration data are discrete in months, as in the case of this study. In the literature, this aspect of the duration data is often ignored and continuous duration models are assumed even when data are discrete. Third, the analyses are conducted for men and women separately, in order to reflect the gender differences in labour market experiences. The main findings include the following. Women have a lower chance of finding a job and leaving unemployment compared to men. Target groups to be helped in finding employment include married women, unmarried men, first-time job seekers, the elderly, individuals with low levels of education and those living in high unemployment provinces. For men, the exit rate from unemployment to employment is found to be higher for vocational high school graduates than for high school graduates. A slight U-shaped duration dependence appears for men and for women an initial flat portion is followed by an up-sloping tendency. This investigation reveals the nature of unemployment in Turkey and has implications for policymakers combating unemployment. Further, analyses in this paper may be of relevance to other countries as well.

This paper is organized into different sections. Section 2 presents background information on the Turkish economy, labour market and the unemployment problem. Section 3 introduces the HLFS (Household Labour Force Survey) data used in the study 
and discusses the construction of unemployment durations based on two alternative definitions of unemployment. The specification of the reduced-form, group duration model is discussed in Section 4. Estimation results are provided in Section 5 and policy implications and conclusions appear in Section 6.

\section{Background on the Turkish Economy, Labour Market and Unemployment}

\subsection{Turkish Economy and the Labour Market}

This section provides information about the recent developments in the Turkish economy and in the labor market in order to contextualize the analysis of unemployment duration for the Turkish case. The Turkish labour market is characterized by strong supply side pressures attributable to rapid population growth, low employment rates, declining participation rates, high unemployment rates, widespread employment in small scale establishments, and segmentation of wages along several lines. Table 1 shows the recent developments in the Turkish economy and the labour market. Recently, Turkey has experienced a series of economic and financial crises, the first of which occurred in the early 1990s due to the adverse effects of the Gulf War. The second crisis, in 1994, was due to financial mismanagement. The economy contracted by about 6 percent, the inflation rate soared to 90 percent and the Turkish Lira was devalued against the US dollar by approximately 70 percent. The third crisis occurred in 1999 and was due to the delayed effect of the Russian crisis and two major earthquakes that occurred in the industrial heartland of the country killing thousands and destroying businesses. Finally, during the 
November 2000 and February 2001 financial crisis, real GNP declined by 9.5 percent, the largest contraction ever in the history of

\begin{tabular}{|c|c|c|c|c|c|c|c|c|}
\hline Indicator & 1988 & 2000 & 2001 & 2002 & 2003 & 2004 & 2005 & 2006 \\
\hline Percapita GNP (\$) & 1684 & 2965 & 2123 & 2598 & 3383 & 4172 & 5008 & 5477 \\
\hline Growth Rate of real GNP \% & 1.5 & 6.3 & -9.5 & 7.9 & 5.9 & 9.9 & 9.6 & 6.0 \\
\hline Non-Institutional Civilian Population ${ }^{\mathrm{a}}$ & 53284 & 66187 & 67296 & 68393 & 69479 & 70556 & 71611 & 72606 \\
\hline Population 15 and above $^{\mathrm{a}}$ & 33746 & 46211 & 47158 & 48041 & 48912 & 49906 & 50826 & 51668 \\
\hline Not in the Labour Force ${ }^{a}$ & 14355 & 23133 & 23667 & 24223 & 25272 & 25616 & 26260 & 26892 \\
\hline Labour Force $^{\mathrm{a}}$ & 19391 & 23078 & 23491 & 23818 & 23640 & 24289 & 24565 & 24776 \\
\hline Employment $^{\mathrm{a}}$ & 17754 & 21581 & 21524 & 21354 & 21147 & 21791 & 22046 & 22330 \\
\hline Rate of growth (\%) & - & - & -0.27 & -0.80 & -0.98 & 3.05 & 1.18 & 1.29 \\
\hline In Agriculture (\%) & 46.5 & 36 & 38.6 & 34.9 & 33.9 & 34 & 29.5 & 27.3 \\
\hline In Manufacturing (\%) & 21.5 & 24.0 & 22.7 & 23.0 & 22.8 & 23.0 & 28.7 & 25.4 \\
\hline In Services (\%) & 32.0 & 40.0 & 37.7 & 42.1 & 43.4 & 43.0 & 41.8 & 47.3 \\
\hline Hours of Work ${ }^{b}$ & 119.0 & 88.1 & 79.0 & 80.7 & 82.3 & 84.6 & 83.7 & 82.8 \\
\hline Unemployed $^{\mathrm{a}}$ & 1638 & 1497 & 1967 & 2464 & 2493 & 2498 & 2520 & 2446 \\
\hline Labour Force Participation (\%) & 57.5 & 49.9 & 49.8 & 49.6 & 48.3 & 487 & 48.3 & 48.0 \\
\hline Men & 81.2 & 73.7 & 72.9 & 71.6 & 70.4 & 72.3 & 72.2 & 71.5 \\
\hline Women & 34.3 & 26.6 & 27.1 & 27.9 & 26.6 & 25.4 & 24.8 & 24.9 \\
\hline Employment Rate (\%) & 52.6 & 46.7 & 45.6 & 44.4 & 43.2 & 43.7 & 43.4 & 43.2 \\
\hline Men & 75.1 & 68.9 & 66.5 & 63.9 & 62.9 & 64.7 & 64.8 & 64.5 \\
\hline Women & 30.6 & 24.9 & 25.1 & 25.3 & 23.9 & 22.9 & 22.3 & 22.3 \\
\hline Unemployment Rate (\%) & 8.4 & 6.5 & 8.4 & 10.3 & 10.5 & 10.3 & 10.3 & 9.9 \\
\hline Men & 7.5 & 6.6 & 8.7 & 10.7 & 10.7 & 10.5 & 10.3 & 9.7 \\
\hline Women & 10.6 & 6.3 & 7.5 & 9.4 & 10.1 & 9.7 & 10.3 & 10.3 \\
\hline Non-Agricultural Unemployment Rate & 14.4 & 9.3 & 12.4 & 14.5 & 13.8 & 14.3 & 13.6 & 12.2 \\
\hline Expanded Unemployment Rate ${ }^{\mathrm{c}}$ & - & 10.9 & 12.3 & 14.0 & 14.0 & 14.6 & 16.1 & 16.9 \\
\hline Youth Unemployment Rate $^{\mathrm{d}}$ & 17.5 & 13.1 & 16.2 & 19.2 & 20.5 & 19.7 & 19.3 & 18.7 \\
\hline Educated Unemployment Rate ${ }^{\mathrm{e}}$ & 15.1 & 9.4 & 11.4 & 13.4 & 12.2 & 14.1 & 12.4 & 11.6 \\
\hline Educated Youth Unemployment Rate ${ }^{f}$ & 38.6 & 21.9 & 25.5 & 29.1 & 27.9 & 30.0 & 26.2 & 24.1 \\
\hline First-Time Job Seekers (\%) & 76.4 & 31.2 & 24.3 & 20.9 & 19.3 & 24.5 & 22.0 & 20.0 \\
\hline Long-Term Unemployed $(\%)^{\mathrm{g}}$ & 49.8 & 20.4 & 20.7 & 28.3 & 23.4 & 38.5 & 39.2 & 34.3 \\
\hline Informal Sector Employment $(\%)^{\text {h }}$ & 58.1 & 50.6 & 52.8 & 52.1 & 51.7 & 53.0 & 50.1 & 48.4 \\
\hline Agricultural & 93.5 & 88.6 & 91.7 & 90.1 & 91.2 & 90.0 & 88.2 & 87.4 \\
\hline Non-Agricultural & 27.4 & 29.2 & 29.5 & 31.7 & 31.5 & 33.9 & 34.2 & 33.9 \\
\hline
\end{tabular}

Source: TUIK's database on the web based on Household Labour Force Surveys.

Notes : a: The figures are in millions.

$\mathrm{b}$ : Working hours index in manufacturing sector

c: This rate includes those who are not looking for a job either because they are discouraged or for other reasons.

d: Refers to the age group 15-24.

e: Refers to the high school, vocational high school and university graduates.

f: Refers to the high school, vocational high school and university graduates of 15-24 age group.

g: Refers to proportion of the unemployed who are looking for a job over one year.

$\mathrm{h}$ : Refers to those who do not have social security coverage. 
the republic. The economy bounced back in 2002 with an impressive growth rate of 7.9 percent. Even though high growth rates were achieved in the following years also, the unemployment rates remained high, which is dubbed as 'jobless growth'. Unemployment rates increased and remained high around 10-11 percent and the unemployment figure stood at approximately 2.5 million people in 2002. The number of employed people declined during 2001-2003. The employment rate declined as well, and in 2006 had not yet increased to its pre-crisis level. Unlike in the previous crises, even the highly educated, such as those in the banking and media sector, were adversely affected and the unemployment rate among the educated reached very high levels. The youth unemployment rate reached nearly 20 percent and the educated youth unemployment rate ranged between $25-30$ percent after the 2001 crisis.

The other side of the coin to unemployment rate is employment. Over the years, the population growth rate in Turkey has exceeded the employment growth rate. The working age population (population of age 15 and above) nearly doubled over the period 19802006. It was 27.1 million in 1980 and increased to 51.7 million in 2006, while employment increased from 18.5 million in 1980 to 22.7 million in 2006. As a result, while working age population increased by 24.9 million, employment increased by 4.2 million over the 1980-2006 period. During and after the 2001 crisis, total employment declined by $0.27,0.80$ and 0.98 percent in 2001, 2002, and 2003, respectively while it increased by 3.8, 1.2 and 1.3 percent in 2004, 2005 and 2006, in spite of the impressive economic growth rates achieved after the 2001 crisis. Similarly, the employment rate declined over the 2000-2006 period, from 46.7 percent in 2000 to 43.2 percent in 2006 . 
The employment rate was 65 percent for men and 22 percent for women in 2006, the lowest rates among the OECD countries. Employment in agriculture is observed to decline over the years as there has been a movement away from low productivity agriculture. The employment rate in agriculture declined from 36 percent in 2000 to 27 percent in 2006, which is still rather high.

Over the period 2000-2006, the labour force increased (by 7.4 percent) at a slower rate than the working age population (by 12 percent) due to declining labour force participation rates (by 4 percent). Tansel (2001, p. 8) shows the rural and urban participation rates by gender over time: There are clear declines in the participation rates of urban men, rural men and rural women while the participation rate of urban women has remained at about the same level since 1988. Urban male and female participation rates were about 71.5 and 19.3 percent, respectively in 2005 . This rate for urban ${ }^{\mathrm{ii}}$ women is remarkably low by international standards. In the rural areas, women engaged in agriculture can combine agricultural activities with household work. However, when they migrate to the cities, combining home and market work becomes harder. Consequently, they concern themselves with household responsibilities and withdraw from the labour force. Women's low levels of education and cultural values against their employment are other reasons for their low participation rates in urban areas (Tansel, 2001). However, among university educated women the participation rate is comparable to those in the OECD countries.

Approximately three-fifths of the urban labour force in Turkey are wage earners, while self-employment for men and unpaid family work for women are prevalent in the 
rural labour force. Employment is mostly in small scale establishments. Establishments with fewer than four workers account for about two-fifth of the urban employment. Informal sector employment has been declining over time and was 48 percent in 2006 . It was 88 percent in the agricultural sector and 34 percent in the non-agricultural sector employment. Relatively high non-wage labour costs, which are about 40 percent of the gross wages, and weak enforcement of the legislation for social security coverage are considered to encourage employment in the informal sector. However, a large wage gap prevails between the formal and informal sectors (Tansel, 2000). Early retirement out of the labour market is another aspect of the Turkish labour market. Until recently, early retirement was encouraged as a solution to unemployment, which led to the collapse of the social security system. The retirement age was recently revised upwards. The new Labour Law introduced in 2003 included job security. However, it applies only to firms with more than 100 workers. In general, the Turkish labour market is considered flexible (Ercan and Tansel, 2007). Unemployment insurance is a recent experience. It was established in 1999; premium collection started in mid 2000 and benefits were paid for the first time in March 2002. Şahin and Kızılırmak (2007) study unemployment insurance benefits in Turkey and find that personal characteristics including age, gender, marital status and education significantly affect the duration of unemployment insurance benefits after controlling for the effects of types of workplace, job types and regions.

\subsection{Unemployment}


A more detailed discussion of unemployment rates in Turkey presents a clearer picture of the unemployment in Turkey. As observed in Table 1, in 2006, the total unemployment rate was 9.9 percent while the non-agricultural unemployment rate was 12 percent. An expanded unemployment figure which includes those who are not looking for a job, either because they are discouraged or for other reasons, was 17 percent. The youth unemployment rate of nearly

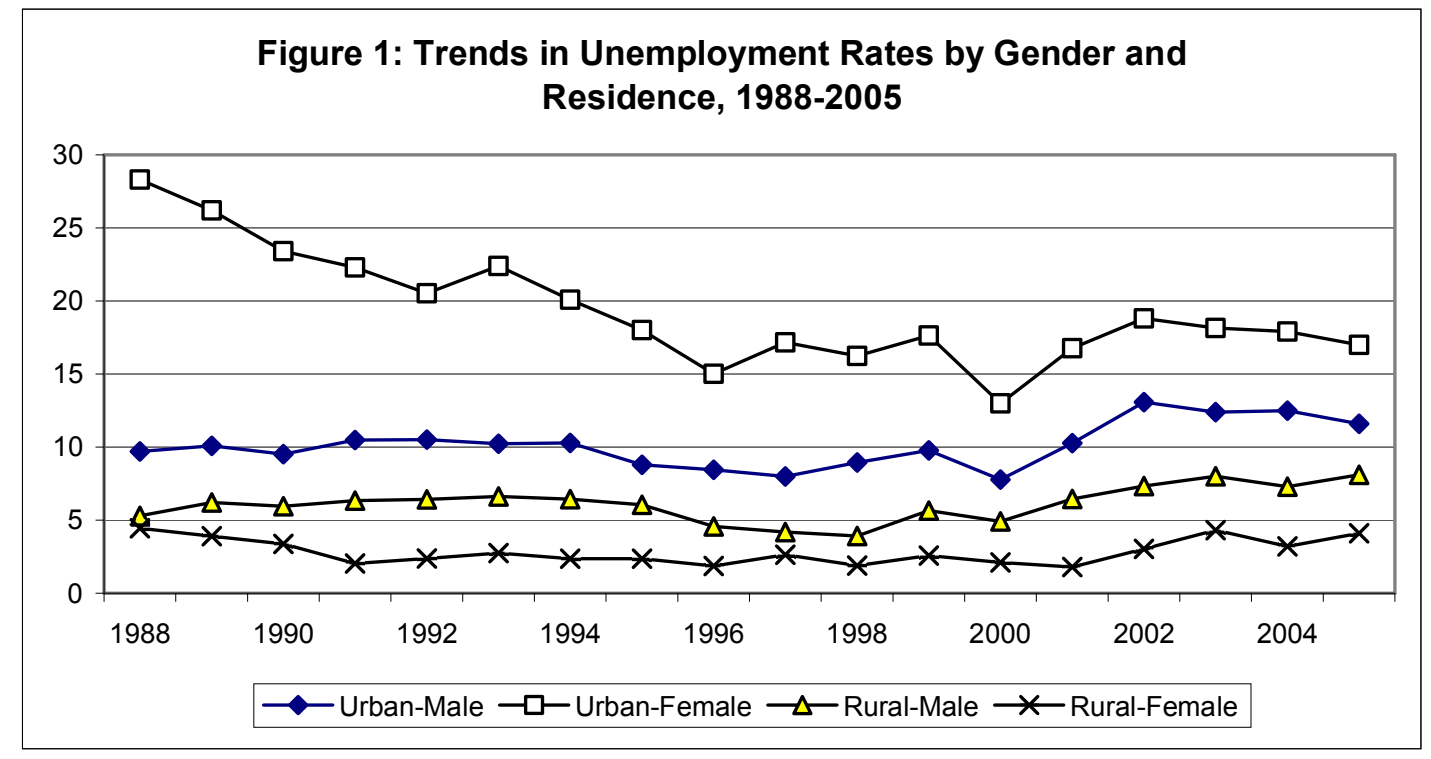

Source: TUIK's database on the web.

20 percent and the educated unemployment rate of 12 percent are rather high. Unemployment rates significantly differ between men and women by location. Figure 1 and Table 2 present the rural and urban unemployment rates by gender for recent years. Figure 1 shows that urban unemployment rates are higher than the rural rates and that the highest rates are for urban women throughout the period. The declining trend reversed in 
2001 due to the 2001 crisis with significant increases in all rates after this year. The low unemployment rates of women in rural areas are due to their high participation rates in rural areas and their ability to combine home and agricultural activities. The high unemployment rates of urban women are related to their low participation rates as discussed in Section 2.1.

Table 2 shows the unemployment rate and the mean unemployment duration by residence, gender, age, education and the seven regions of Turkey. Unemployment rates by the seven geographic regions given for men and women separately reveal large variations in these rates, as is the case with GDP (gross domestic product) generated in these regions. Per capita GDP is highest in the Marmara region and lowest in the NorthEast, East and South-East Anatolia regions. . In general, mean unemployment durations were found to be higher for women than for men. The Mediterranean region held the highest male unemployment rates in 2000 and 2001. The highest male unemployment regions were South-East Anatolia and Marmara in 2002, and South-East Anatolia and the Mediterranean in 2003. The lowest male unemployment region was the Black Sea for all the years between 2000 and 2003. The Mediterranean region held the highest female unemployment rate in 2000. For the 2001-2002 period the Marmara region, and for 2003, the South-East Anatolia region had the highest female unemployment rates. Throughout the 2000-2003 period, the Black Sea and East Anatolia regions had the lowest female unemployment rates. In the latter two regions also the highest mean unemployment duration was observed, while South-East Anatolia had the lowest mean unemployment 
duration. The latter observation is somewhat surprising and may be due to the fact that unemployment may not be a good measure of inactivity in a less developed region. There was a significant increase in both the male and the female unemployment rates

\begin{tabular}{|c|c|c|c|c|c|c|c|c|}
\hline \multirow[b]{2}{*}{ Category } & \multicolumn{4}{|c|}{ Rate of Unemployment \% } & \multicolumn{4}{|c|}{ Mean Unemployment Duration (months) } \\
\hline & 2000 & 2001 & 2002 & 2003 & 2000 & 2001 & 2002 & 2003 \\
\hline \multicolumn{9}{|l|}{ Residence \& Gender } \\
\hline Urban-Male & 7.8 & 10.3 & 13.0 & 12.6 & 7.17 & 6.79 & 8.94 & 8.70 \\
\hline Urban-Female & 13.0 & 16.6 & 18.7 & 18.3 & 9.20 & 8.90 & 10.50 & 10.87 \\
\hline Rural-Male & 4.9 & 6.5 & 7.3 & 7.9 & 6.21 & 6.76 & 7.94 & 6.38 \\
\hline Rural-Female & 2.0 & 1.7 & 3.0 & 4.0 & 9.54 & 10.88 & 10.58 & 7.57 \\
\hline \multicolumn{9}{|l|}{ Male by Region } \\
\hline Marmara & 7.7 & 9.7 & 12.9 & 10.7 & 6.31 & 6.85 & 9.52 & 8.95 \\
\hline Aegean & 7.5 & 8.3 & 10.5 & 10.9 & 6.24 & 7.87 & 8.81 & 7.99 \\
\hline Mediterranean & 8.1 & 11.2 & 11.9 & 11.4 & 7.35 & 7.78 & 9.08 & 7.58 \\
\hline Central Anatolia & 5.4 & 8.3 & 9.8 & 9.9 & 8.76 & 5.57 & 6.97 & 8.86 \\
\hline $\begin{array}{l}\text { Black Sea } \\
\end{array}$ & 4.1 & 4.1 & 6.0 & 5.8 & 8.62 & 6.22 & 7.51 & 6.25 \\
\hline East Anatolia & 4.3 & 9.4 & 8.0 & 7.9 & 5.5 & 6.01 & 8.57 & 8.93 \\
\hline South-East Anatolia & 7.5 & 10.2 & 13.2 & 20.9 & 5.48 & 6.32 & 8.38 & 5.90 \\
\hline \multicolumn{9}{|l|}{ Female by Region } \\
\hline Marmara & 10.5 & 12.6 & 14.7 & 14.9 & 7.09 & 8.24 & 10.02 & 10.50 \\
\hline Aegean & 7.6 & 9.2 & 10.5 & 10.2 & 9.57 & 11.35 & 10.97 & 8.78 \\
\hline Mediterranean & 11.9 & 10.9 & 12.5 & 9.4 & 10.87 & 9.72 & 11.12 & 10.89 \\
\hline Central Anatolia & 5.8 & 8.6 & 10.2 & 11.6 & 10.89 & 7.61 & 10.74 & 11.08 \\
\hline Black Sea & 2.4 & 2.4 & 3.1 & 3.4 & 14.48 & 12.21 & 10.54 & 14.32 \\
\hline East Anatolia & 0.7 & 2.4 & 3.0 & 2.5 & 9 & 15.05 & 13 & 14.85 \\
\hline South-East Anatolia & 4.1 & 4.8 & 9.6 & 24.1 & 4.36 & 5.11 & 10.69 & 6.84 \\
\hline \multicolumn{9}{|l|}{ Age Group } \\
\hline 15-19 & 10.8 & 15.1 & 17 & 17.7 & 6.1 & 6.1 & 7.3 & 6 \\
\hline $20-24$ & 14.7 & 17.2 & 20.7 & 21.7 & 7.4 & 7.3 & 8.4 & 7.8 \\
\hline 25-34 & 6.4 & 8.3 & 10.8 & 11.1 & 8 & 7.6 & 9.4 & 9.2 \\
\hline 35-54 & 3.6 & 4.8 & 6.6 & 6 & 7.6 & 8 & 10.2 & 9.5 \\
\hline 55 and over & 1.2 & 1.5 & 2.3 & 2.1 & 11.1 & 9.3 & 12.1 & 12.1 \\
\hline \multicolumn{9}{|l|}{ Level of Education } \\
\hline No Formal Education & 4.4 & 4.3 & 5.9 & 8.3 & 5.9 & 6 & 7.8 & 6.9 \\
\hline Primary School & 4.8 & 6.8 & 8.3 & 8.8 & 6.5 & 6.6 & 8.4 & 7.4 \\
\hline
\end{tabular}




\begin{tabular}{|r|c|c|c|c|c|c|c|c|}
\hline Middle School & 10.3 & 14.6 & 14.9 & 14.6 & 7.3 & 7.8 & 9.7 & 9.4 \\
\hline High School & 12.7 & 15.7 & 18.1 & 15.7 & 9.8 & 8.9 & 10.5 & 10.5 \\
\hline Voc. High School & 12.7 & 16.2 & 18.4 & 15.5 & 8.9 & 7.9 & 9.4 & 10.1 \\
\hline University & 7.4 & 8.2 & 11.9 & 12 & 7.5 & 8.2 & 10.3 & 9.7 \\
\hline Overall & 6.6 & 8.3 & 10.4 & 10.4 & 7.5 & 7.4 & 9.1 & 8.6 \\
\hline
\end{tabular}

Source: The unemployment rates and the mean unemployment durations in months are computed by the authors from the TUIK's database on the web.

Notes: The data on the mean unemployment duration are obtained from the TUIK's database on the web. On the website the duration values are reported for the following month groups: 1-2, 3-5, 6-8, 9-11, 12-23, 24-35, and 36+.The group means are set at the following values $1.5,4,7$, $10,14,25$ and 52 as was done by Tunali et al. (2004).

in the South-East Anatolia region from 2002 to 2003. An explanation of these increases as well as the wide regional differentials require an examination of the regional migration patterns, employment structure and employment creation patterns among other factors, which is beyond the scope of this paper.

Table 2 shows that unemployment rates among older workers (55 and over) are very low, however, with very high mean unemployment durations. In contrast, youth (1524 age groups) unemployment is especially high with remarkably low mean unemployment durations. This is a fairly common finding in developed countries and caused by the fact that school leavers tend to leave school at the same time (causing high unemployment rates), but typically enter work fairly quickly (causing low unemployment duration). Short unemployment duration is also related to job shopping behavior among young workers, who may try a variety of different jobs in order to find a suitable workerfirm match. Various characteristics of youth unemployment duration are studied by Taşç1 and Tansel (2005). In terms of education levels, the lowest unemployment rates and durations are observed for the category of no formal educational qualifications, which includes illiterates and literates with no diploma, and for the category of primary school graduates with five years of schooling, which is approximately the average years of 
schooling of the labour force. The highest unemployment rates and durations are observed among high school and vocational high school graduates. The unemployment rate of university graduates has increased disproportionately over the period studied. Furthermore, the mean duration of unemployment among university graduates appears to be longer relative to the typical situation in developed countries, though somewhat shorter than is the case in developing countries.

\section{The Data and Unemployment Definitions}

\subsection{The Household Labour Force Survey and Sampling Issues}

In this study, we use the Household Labour Force Survey (HLFS) which has been carried out quarterly by TUIK with a panel feature since 2000. For this study, three

quarters (Q1, Q2 and Q4) from the 2000 survey and two quarters (Q1 and Q2) from the 2001 survey are used. There are approximately 23,000 households in every quarter in both 2000 and 2001. The sample is restricted to individuals between 15-65 years of age who are potential labour market participants. 15 is the legal age to start work and 65 is the age when most individuals retire from work. Approximately half of the individuals surveyed in the first quarter of 2000 were re-interviewed in the second quarter of 2000 in such a way that with the fresh additions, the sample is still representative of the country. This allows us to follow whether or not the unemployed individuals find employment. The subgroups used to construct unemployment durations were interviewed minimum twice in two subsequent quarters or one year apart. Some respondents may have moved elsewhere to take up a job or to follow their partner or 
refused to be interviewed. If moving to take up a job is substantial, then the unemployed may be overrepresented in the panel data set and bias the results. The sample attrition was about 7 percent between the first and second quarters of 2000. To address the potential problem of self-selection, a series of robustness analyses were performed ${ }^{\mathrm{iii}}$. The results indicated that the potential problem of self selection was not significant. Therefore, the total number of observations was used in the analysis of this paper.

The Turkish Household Labour Force Survey (HLFS) samples the individuals at a given point in time and records or observes the individual's elapsed duration of the unemployment spell from the retrospective question number 40, 'How long have you been seeking a job (in months)?' (See SIS, 2001b: appendix-6: p.3) ${ }^{\mathrm{iv}}$. This sampling plan is referred to as 'stock sampling' in the literature (See Lancaster 1990, Addison and Portugal, 2002 and 2003, and Wooldridge 2002). The most important problem is that sampling from the stock of people at a given date results in 'length-biased sampling' (Wooldridge, 2002, -p.700- defines this as 'left-truncation' problem). This can be attributed to the fact that the unemployment durations in progress at the conduction time of the survey are more likely to be 'long' unemployment durations than 'short' ones (Kiefer, 1988, p.647). Thus, long unemployment spells are overrepresented and spells just finished before the survey conduction time are not observed and therefore, cannot be included in the analysis. The Turkish HLFS also carries rotating panel features, which enable it to remain representative of the country (SIS 2001b). With this property, the stock of unemployed individuals (as well as other individuals who are in the other labour market states) can be followed up over a fixed time interval of fixed lengths to determine 
whether they found a job. Given the above discussions, to deal with the unemployment duration data type in question, the conditional likelihood approach can be used to avoid stock sample biases (Guo, 1993 and Bower and Gomez 2004). In this approach, we have to condition on elapsed time in unemployment on the first survey date to recover the entrant density function (Addison and Portugal, 2003, p. 164).

In the analysis, the responses of unemployed individuals to the question mentioned above $^{\mathrm{v}}$ are used. The data set obtained covers a total of 4834 and 6983 unemployed individuals (for 2000 and 2001 combined) under the ILO and the broad definitions, respectively ${ }^{\mathrm{vi}}$. The unemployment durations were computed using two different methods. The first is the elapsed (backward) unemployment duration in months in the stocks of unemployed at each interview date for the individuals who are still unemployed. These define the right-censored spell durations. The second is defined as follows. If an individual in one wave leaves unemployment for a job before the next interview, then all that is known is that unemployment ended between the two interviews ${ }^{\mathrm{vii}}$. There is an unobserved period and it is not possible to know exactly how much of this period is actually spent in unemployment. (Following the literature, the possibility that several short unemployment spells may happen during the unobserved periods is ignored.) These define the interval-censored spell durations. There are 1089 and 1555 interval-censored observations under the ILO and broad definitions, respectively ${ }^{\text {viii }}$.

\subsection{Two Unemployment Definitions and Their Incidence}


The Turkish Statistical Institute uses the International Labour Organization (ILO)'s definition of unemployment. According to this definition, the unemployed are comprised of all persons 15 years of age and over who are not employed during the reference period, who have used at least one of the search channels to seek a job during the last three months and who are available to start work within 15 days (SIS, 2001b). This definition covers individuals in the informal sector as well ${ }^{\mathrm{ix}}$ and is referred to as 'ILO unemployment'. In the early 1980s, the ILO advocated relaxing the job search requirement in the definition of unemployment for developing countries. In developing countries, the conventional job-search channels may not be very relevant in the urban labour markets where labour absorption is low, and in the rural labour markets where self-employment and unpaid family work (especially for women) are prevalent (See Hussmanns et al., 1990, Byrne and Strobl, 2004). These conditions are largely observed in Turkey as a developing country. Therefore, in this study, the requirement of actively searching for a job in the ILO unemployment definition is omitted and the resulting definition referred to as 'broad unemployment' ${ }^{\mathrm{x}}$. Those who are out of the labour force are excluded from both the ILO and the broad definition. It is often hard to distinguish between unemployment and economic inactivity among women, particularly if searching for a job is not used to determine unemployment, such as in the broad definition. This raises the question of whether many of these individuals are really unemployed or out of the labour force, which is an issue addressed in the literature ${ }^{\mathrm{xi}}$.

The unemployment rates under alternative definitions are provided in Table 3. This table shows that broad unemployment rates are higher than the ILO unemployment 
rates, particularly in urban locations by about four percentage points in both 2000 and 2001. For urban women, the increase is about 6 percentage points in case of a move from the ILO to the broad definition. Kingdon and Knight (2000) found for South Africa that the unemployment rate was higher by 15 percentage points in 1997 when the broad definition was used. Byrne and Strobl (2004) found for Trinidad and Tobago that the unemployment rate was higher by 3.6 percentage points for men and by 7.2 percentage points for women when the broad definition was used. Regardless of the definition of unemployment used, Table 3 re-iterates the following. First, the unemployment rates are higher in 2001 than in 2000 for all groups. This increase is due to the severe economic and financial crisis of February 2001. Second, the unemployment rates in urban locations are higher than rates recorded in rural locations. Third, the highest unemployment rates are observed for urban women, which are also higher than those for urban men. Tansel (2001) reports very high levels of hidden unemployment among urban women in Turkey. Hence is the need to study the unemployment duration of women separately.

\begin{tabular}{|c|c|c|c|c|c|}
\hline & & \multicolumn{2}{|c|}{2000} & \multicolumn{2}{|c|}{2001} \\
\hline & & ILO & Broad & ILO & Broad \\
\hline \multirow[t]{3}{*}{ All } & Total & 6.60 & 9.46 & 8.50 & 11.43 \\
\hline & Male & 6.63 & 9.29 & 8.78 & 11.61 \\
\hline & Female & 6.49 & 9.85 & 7.86 & 11.15 \\
\hline \multirow[t]{3}{*}{ Urban } & Total & 8.80 & 12.39 & 11.50 & 15.36 \\
\hline & Male & 7.77 & 10.70 & 10.27 & 13.54 \\
\hline & Female & 13.00 & 19.40 & 16.76 & 23.15 \\
\hline \multirow[t]{3}{*}{ Rural } & Total & 4.00 & 5.96 & 4.80 & 6.54 \\
\hline & Male & 4.92 & 7.27 & 6.46 & 8.64 \\
\hline & Female & 2.11 & 3.27 & 1.79 & 2.81 \\
\hline
\end{tabular}

Source: Computed by the authors using HLFS 2000 and 2001

Notes: These rates are computed as percentages of individuals in each group. Broad Unemployment is obtained by dropping the criterion of seeking work. 
Table 4 presents the percentage distribution of unemployment duration by gender. The percentage of the long-term unemployed (see last column) is higher among women than among men under both definitions of unemployment. Further, the percentage of the long-term unemployed is highest for the older age groups and for the high school graduates but lowest for university graduates (not shown) (see also Tansel and Tasci, 2004). The average truncated (or right censored) duration of unemployment for all individuals is 6.7 and 8.7 months under the ILO and broad definitions, respectively. These unemployment durations in Turkey are shorter than in other developing countries. Dickens and Lang (1996) report 4 years of unemployment duration in Sri Lanka and Kingdon and Knight (2000) report about 3 years of unemployment duration for a group of the unemployed. Dendir (2006) reports that in urban Ethiopia, the mean unemployment (broad definition) duration is three years for the completed spells and 4.7 years for incomplete spells. These observations indicate that even the broad definition of unemployment is far too narrow and that non-employment in general in the developing countries needs to be investigated whereby the non-employment includes those who are unemployed and those who are out of the labor force. The distinction between the unemployed and the out of the labor force is arbitrary and for measurement purposes. A vast literature has developed investigating the dividing line between the unemployed and the out of the labor force ( inactivity) in the developed countries. Clark and Summers (1979; 1982), Flinn and Heckman (1983) and Gönül (1992) investigated this issue in the USA (also see Footnote 11). Clark and Summers (1979) in general and Clark and Summers (1982) for teenagers found that unemployment and out of the labor force are not distinct labor market states while Flint and Heckman found the opposite for 
white male high school graduates in that unemployment and out of the labor force are behaviorally distinct labor market states. Gnul found that while for young women the two states are distinct, for young men they are

\begin{tabular}{|r|r|c|c|c|c|c|c|}
\hline \multicolumn{7}{|c|}{ Table 4: Unemployment Duration by Gender-, Turkey 2000-2001 (\%) } \\
\hline \multicolumn{2}{|c|}{} & $\mathrm{N}$ & $\mathrm{K}=3$ month & $4-6$ month & $\begin{array}{l}7-9 \\
\text { month }\end{array}$ & $\begin{array}{l}10-11 \\
\text { months }\end{array}$ & $\begin{array}{l}12 \text { months } \\
\text { and Over }\end{array}$ \\
\hline $\begin{array}{r}\text { ILO } \\
\text { definition }\end{array}$ & Male & 3532 & 56.94 & 20.55 & 4.39 & 1.84 & 16.28 \\
\cline { 2 - 8 } & Female & 1302 & 44.09 & 20.28 & 4.22 & 2.54 & 28.8 \\
\hline $\begin{array}{r}\text { Broad } \\
\text { definition }\end{array}$ & Male & 4956 & 41.53 & 24.64 & 6.72 & 2.7 & 24.7 \\
\cline { 2 - 8 } & Female & 2027 & 29.26 & 21.81 & 6.27 & 3.3 & 40.01 \\
\hline
\end{tabular}

Source: See Table 3 .

Notes: See Table 3.

not. There are further studies which investigated the selected subgroups of the out of the labor labor force who might behave similar to the unemployed. Such studies include Jones and Riddell (1999; 2006) for Canada; Schweitzer (2003) for the UK; Garrido and Toharia (2004) for Spain and Brandolini et al. (2006) for Italy. Suryadarma (2007) is the only study we encountered which investigate a similar issue in Indonesia, a developing country. The issue of whether unemployment and out of the labor force are behaviorally distinct labor market states needs to be investigated in particular in the developing countries. In Turkey out of the labor force men constituted 26 and women 73 percent of the population 15 and above. Thus, a fruitful way of enhancing our understanding of the labor market dynamics would be to investigate the non-employed in Turkey especially in the case of women which is deferred for future study.

\section{The Econometric Model}


The factors that affect the probability of exit from unemployment to employment are in general examined within the framework of the hazard function. Steiner (201, p.93) states that 'the hazard rate from unemployment can be interpreted as the reduced form of a standard job-search model'. In the job-search model, the costs and benefits of jobsearch and unemployment determine the intensity of the job-search and the reservation wage of the individual. The reservation wage is compared to the offers from the wage distribution. The offers are accepted or declined depending on whether they are above or below the reservation wage. High wage offers relative to the reservation wage or low reservation wages relative to wage offers imply high exit rates from unemployment if the probability of exit from unemployment is assumed to be given by the product of the likelihood of accepting a job offer and acceptance probability. The likelihood of obtaining employment depends on individual characteristics such as gender, age, education, reservation wage, wage offer, search intensity, time spent in unemployment as well as labour market conditions, such as the local unemployment rate. These form the basis of the model employed in this study.

The focus of interest in formulating the econometric model is on the probability that the spell of unemployment will end in the next short interval of time, say $d t$, given that it has lasted until time t. This defines the hazard function, which is a very popular way of analyzing duration data for several reasons. This model can handle censored durations as well as time-varying covariates and allows examination of duration dependence (Ham and Rea, 1987). In the empirical literature, the time variable (T) is taken as a continuous random variable (for example, Grogan and van den Berg, 
2001) for convenience. However, in practice, $T$ is usually available in 'weekly' or 'monthly' form or 'grouped into time intervals', as in this study. Kiefer (1988) refers to this as the 'grouped duration data'. Bergström and Edin (1992) show that biased estimators result from treating grouped data as if they are continuous. The theoretical developments of the hazard function and the associated likelihood function with the grouped duration data are provided by Prentice and Gloeckler (1978), Kiefer (1988), Han and Hausman (1990), Guo (1993) and Sueyoshi (1995). In the literature, a few studies exist that use grouped duration methodology due to Kiefer (1988) and Sueyoshi (1995). Among these, Jenkins and Serrano (2004) use this methodology directly and Böheim and Taylor (2000) use a grouping procedure similar to the one in this paper ${ }^{x i i}$ The grouped nature of the unemployment duration data at hand is explicitly taken into account. The right censored data due to individuals who have not completed their unemployment spells are also taken into account in this approach by including them explicitly in the definition of the likelihood function. The conditional probability of leaving unemployment or the exit rate or the discrete time hazard rate is given by:

$h_{i}(t)=1-\exp \left[-\exp \left(X_{i}(t) \beta+\delta(t)\right]\right.$

where $\mathrm{i}$ denotes the individual, $\mathrm{X}$ is a set of covariates, $\beta$ are the coefficients to be estimated and $\delta(t)$ is the logarithm of the integral of the baseline hazard which is estimated along with the elements of $\beta^{\text {xiii }}$. In this paper, we analyze only the transition from unemployment to full-time wage employment. ${ }^{\text {xiv }}$ We treat the transitions to other labour market states as right censored at the point of exit as it is done in the literature. This is referred to as independence between risks or transition probabilities (see for example, Narendranathan and Stewart, 1993; Carling et al., 1996, Gonzalo, 1998 and 
Addison and Portugal, 2003). In the estimations, the three alternative specifications by the hazard rate for the grouped duration approach following Sueyoshi (1995) are considered. These are the Proportional Hazard Model (PHM) and two non-proportional hazard models, namely, the Log-Logistic and the Log-Normal models, all with the grouped duration approach. The details of these specifications can be found in Kiefer (1988), Guo (1993), Jenkins (1995) and Sueyoshi (1995) ${ }^{\mathrm{xv}}$.

\section{Estimation Results}

\subsection{Non-Parametric Duration Analysis ${ }^{x v i}$}

This section involves non-parametric methods, which do not impose strong assumptions for data exploration and description. The Turnbull's survivor function given in Figure 2 is a generalization of the Kaplan-Meier survivor function for the interval censored data. The survivor function shows the proportion of people who did not experience the event, i.e., who are still in the original state, which in our case, is unemployment. The graphs imply that women have longer unemployment durations than men. The survivor function for men declines more steeply than that for women, implying that unemployed men find jobs sooner than unemployed women. The probability of surviving beyond 12 months is approximately 89.7 percent for women and 70.9 percent for men. The survivor functions also show that unemployment durations are longer in urban locations than in rural locations. The probability of surviving beyond 12 months is about 77.0 and 71.7 percent for the unemployed in urban and rural locations, respectively. 
Figure 2:Turnbull's Survival Function under ILO-Definition
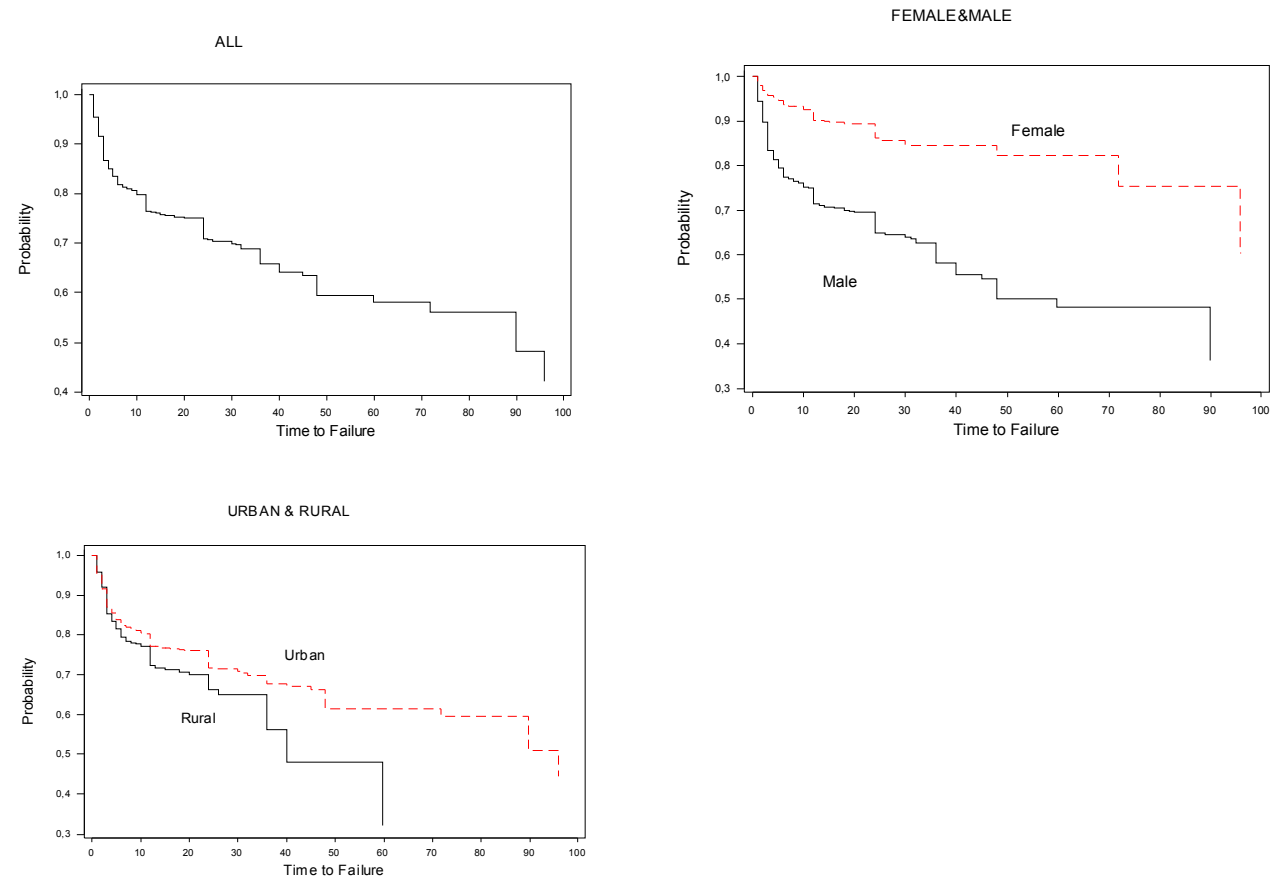

Note: Horizontal axis is 'time to failure.'

Figure 3 presents the plots of the hazard functions for the entire data set, male and female samples. Although there are many peaks, the hazards are constant and always stay below 2.0 percent in all cases. Furthermore, hazard rates are always larger for men than for women. The log-rank test results to test the equality of two or more survivor functions are reported in Table 5. The equality of the survivor functions for men versus women, for different age groups, for first-timers versus non-first-timers and for married versus non-married, are all rejected. However, the equality of survivor functions for university graduates versus other levels of education are rejected only in the male and female samples, and that for the rural versus urban locations is rejected only in the total sample. 
Figure 3: Estimates of the Hazard Functions under ILO Definition

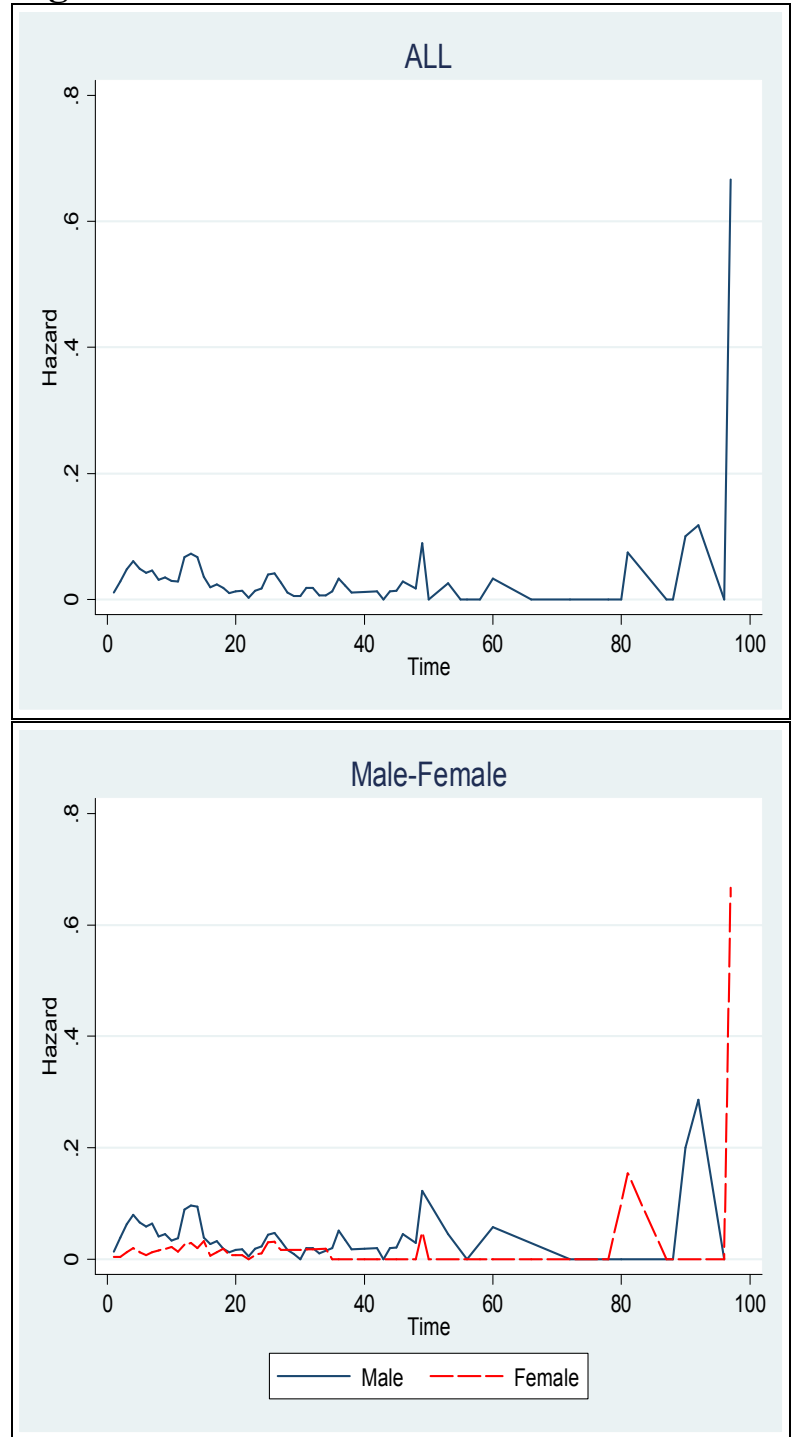

Note: 'Time' measures 'months of unemployment.' 


\begin{tabular}{|l|c|c|c|}
\hline \multicolumn{3}{|c|}{$\begin{array}{c}\text { Table 5: Log Rank Test of Differences in Hazard Rates of Selected Labor } \\
\text { Market Groups Under ILO Definition of Unemployment }\end{array}$} \\
\hline Labor Force Groups & All & MALE & FEMALE \\
\hline Male/Female & $214.6^{* * *}$ & - & - \\
\hline Age Group & $29.15^{* * *}$ & $26.32 * * *$ & 4.16 \\
\hline First-time/Non-First time & $109.9^{* * *}$ & $42.04 * * *$ & $11.89^{* * *}$ \\
\hline Married/Non-Married & $74.2^{* * *}$ & $44.25^{* * *}$ & $5.42^{* *}$ \\
\hline University Graduate/Others & 2.44 & $2.67^{*}$ & $9.22^{* * *}$ \\
\hline Urban/Rural & $6.54^{* * *}$ & 1.26 & 0.44 \\
\hline
\end{tabular}

*** Significant at $1 \%$; ** Significant at $5 \%$; Significant at $10 \%$

Source: See Table 2 .

Note: Age groups are: age 15-19, 20-24, 25-34, 35-44, 45-54, above 55

\subsection{Semi-Parametric Estimation}

The models under the PHM, Log-Logistic and Log-Normal grouped duration specifications are estimated with the ILO and broad definitions of unemployment ${ }^{\text {xvii }}$. The proportionality assumption in the PHM model states that the effect of the covariates on the coefficient is multiplicative. The proportionality assumption is tested by using the two types of Likelihood-Ratio tests due to Kiefer (1988). These tests reject the PHM for the pooled sample under both definitions of unemployment and for the male sample under the ILO definition ${ }^{\text {xviii }}$. These tests yielded conflicting results about the choice of the PHM versus the two non-proportional hazard models, namely, the LogLogistic and Log-Normal models. Since these models are non-nested, they are compared by using Akaike's Information Criterion (AIC). The AIC values for these models are very close to each other, rendering a close choice. Furthermore, the coefficient estimates are very similar under alternative distributions ${ }^{\mathrm{xix}}$. Unobserved heterogeneity arises if some differences remain in the hazards after including all relevant observed factors. Motivation and ability are examples of some of the unobserved 
factors $^{\mathrm{xx}}$. In the estimations, the unobserved heterogeneity term is included using a Gaussian distribution with unit mean and constant variance. The models are estimated with and without unobserved heterogeneity. Unobserved heterogeneity is rejected in all the models for both definitions of unemployment ${ }^{\mathrm{xxi}}$. Therefore, Table 6 reports the results under Log-Normal distribution without the unobserved heterogeneity. Note that for ease in interpreting the parameters, the explanatory variables ${ }^{\mathrm{xxii}}$ are measured as deviations from their means, as suggested by Kiefer (1988) and Sueyoshi (1995). 'Wald Chi2' is the Wald Chi-Squared test statistic for the overall significance of the model.

\section{The Covariate Effects ${ }^{\text {xxii }}$}

Table 6 presents the estimation results of the hazard model under Log-Normal distribution for transitions from unemployment to employment ${ }^{\mathrm{xxiv}}$ for the total, male and female samples separately by using the ILO definition of unemployment ${ }^{\mathrm{xxv}}$. Pooling the male and female samples is rejected. The results obtained using the ILO and broad definitions are similar. The discussion below will point out when these differ. The coefficient estimates on living in an urban location are negative for men and positive for women, but not significant. 
Table 6: Duration Analysis of Exit from Unemployment with Grouped Duration

Log-Normal Hazard Model, ILO Definition, TURKEY 2000-2001

\begin{tabular}{|c|c|c|c|}
\hline & Full & Male & Female \\
\hline Urban & -0.056 & -0.069 & 0.087 \\
\hline & [0.048] & [0.051] & {$[0.152]$} \\
\hline Female & $\begin{array}{c}-0.408^{* * *} \\
{[0.056]}\end{array}$ & & \\
\hline Married & $0.269^{* * *}$ & $0.270^{* * *}$ & $-0.191^{*}$ \\
\hline & [0.052] & {$[0.055]$} & {$[0.115]$} \\
\hline Married*Female & $\begin{array}{c}-0.501^{* * *} \\
{[0.106]}\end{array}$ & & \\
\hline \multicolumn{4}{|l|}{$\begin{array}{l}\text { Region of Residence } \\
\text { (Base: Central } \\
\text { Anatolia) }\end{array}$} \\
\hline Marmara & $\begin{array}{c}0.035 \\
{[0.0591}\end{array}$ & $\begin{array}{l}-0.004 \\
{[0.0641}\end{array}$ & $\begin{array}{c}0.238 \\
{[01641}\end{array}$ \\
\hline \multirow[t]{2}{*}{ Aegean } & 0.011 & -0.034 & 0.229 \\
\hline & {$[0.067]$} & [0.074] & {$[0.179]$} \\
\hline \multirow[t]{2}{*}{ Mediterrianean } & 0.074 & 0.061 & 0.170 \\
\hline & [0.064] & [0.071] & {$[0.177]$} \\
\hline \multirow[t]{2}{*}{ Black Sea } & -0.109 & -0.116 & -0.071 \\
\hline & {$[0.071]$} & [0.079] & [0.187] \\
\hline \multirow[t]{2}{*}{ East Anatolia } & $0.135^{*}$ & 0.125 & -0.206 \\
\hline & {$[0.081]$} & [0.084] & [0.428] \\
\hline \multirow[t]{2}{*}{ South-East Anatolia } & $0.244^{* * *}$ & $0.283^{* * *}$ & -0.639 \\
\hline & {$[0.075]$} & {$[0.080]$} & [0.412] \\
\hline $\begin{array}{l}\text { Education Level (Base: } \\
\text { No Formal Educational } \\
\text { Qualification) }\end{array}$ & & & \\
\hline Primary School & $\begin{array}{l}0.544^{* * *} \\
{[0.102]}\end{array}$ & $\begin{array}{l}0.527^{* * *} \\
{[0.103]}\end{array}$ & $\begin{array}{l}0.911^{*} \\
{[0.506]}\end{array}$ \\
\hline Middle School & $\begin{array}{l}0.423^{* * *} \\
{[0.108]}\end{array}$ & $\begin{array}{l}0.382^{* * *} \\
{[0.109]}\end{array}$ & $\begin{array}{l}0.993^{*} \\
{[0.534]}\end{array}$ \\
\hline High School & $\begin{array}{l}0.349^{* * *} \\
{[0.112]}\end{array}$ & $\begin{array}{l}0.267^{* *} \\
{[0.115]}\end{array}$ & $\begin{array}{l}1.00{ }^{*} \\
{[0.528]}\end{array}$ \\
\hline Vocational High & & & \\
\hline School & $\begin{array}{l}0.424^{* * *} \\
{[0.118]}\end{array}$ & $\begin{array}{c}0.426^{* * *} \\
{[0.122]}\end{array}$ & $\begin{array}{c}0.745 \\
{[0.519]}\end{array}$ \\
\hline Two-Year University & $\begin{array}{l}0.775^{\star * \star} \\
{[0.136]}\end{array}$ & $\begin{array}{l}0.652^{* * *} \\
{[0.153]}\end{array}$ & $\begin{array}{l}1.477^{* * *} \\
{[0.516]}\end{array}$ \\
\hline $\begin{array}{l}\text { Four-Year Univ. and } \\
\text { over }\end{array}$ & $0.585^{* * *}$ & $0.290^{*}$ & $1.542^{* * *}$ \\
\hline
\end{tabular}




\begin{tabular}{|l|l|l|l|} 
& {$[0.136]$} & {$[0.157]$} & {$[0.548]$} \\
\hline
\end{tabular}

Notes: 1) Robust standard errors in brackets

2) * significant at $10 \% ; *$ significant at $5 \% ; * *$ significant at $1 \%$

3) For brevity we do not provide the values of period specific constants that measure the duration dependence 
Table 6 (continued)

\begin{tabular}{|l|c|c|c|}
\hline & Full & Male & Female \\
\hline Age-Group (Base Age 15-19) & & & \\
Age 20-24 & -0.021 & 0.008 & $-0.264^{* *}$ \\
& {$[0.061]$} & {$[0.071]$} & {$[0.120]$} \\
Age 25-34 & $-0.121^{*}$ & -0.104 & $-0.312^{* *}$ \\
& {$[0.064]$} & {$[0.075]$} & {$[0.133]$} \\
Age 35-44 & $-0.132^{*}$ & -0.090 & $-0.374^{* *}$ \\
& {$[0.075]$} & {$[0.085]$} & {$[0.188]$} \\
Age 45-54 & $-0.333^{* * *}$ & $-0.303^{* * *}$ & $-0.459^{*}$ \\
& {$[0.087]$} & {$[0.096]$} & {$[0.274]$} \\
Age 55+ & $-0.468^{* * *}$ & $-0.412^{* * *}$ & $-4.032^{* * *}$ \\
& {$[0.123]$} & {$[0.129]$} & {$[0.193]$} \\
\hline Unemployment rate & $-2.636^{* * *}$ & $-2.415^{* * *}$ & $-4.317^{* * *}$ \\
& {$[0.418]$} & {$[0.452]$} & {$[1.140]$} \\
First-time Job-Seeker & $-0.232^{\star * *}$ & $-0.175^{* * *}$ & $-0.415^{* * *}$ \\
& {$[0.048]$} & {$[0.058]$} & {$[0.093]$} \\
\hline Wald chi2 & 5389.5 & 3606.4 & 38283.2 \\
Prob>chi2 & 0.000 & 0.000 & 0.000 \\
\hline Log-Likelihood & -3194.5 & -2676.3 & -483.2 \\
\hline Observations (person-period) & 11544 & 7816 & 3728 \\
\hline
\end{tabular}

Notes: 1) Robust standard errors in brackets

2) * significant at $10 \% ; * *$ significant at $5 \% ; * * *$ significant at $1 \%$

3 ) For brevity we do not provide the values of period specific constants that measure the duration dependence

When the broad definition is employed, the coefficient estimate is significant for men, which indicates that men have higher exit rates in urban locations than in the rural areas. In the pooled sample, the negative coefficient estimate on the female dummy variable is highly significant, which indicates that women have significantly lower exit rates from unemployment to employment than men. This is in contrast to what Grogan and van den Berg (2001) found with the Russian data. Several explanations for this observation can be given. One is that women may be less likely to search for a job than men or they may 
receive fewer job offers than men. Another is that women may have higher reservation wages. Furthermore, the negative coefficient estimate on the interaction dummy of the married with female indicates that married women experience significantly lower exit rates from unemployment to employment than non-married women. The effects of marital status on the hazard rate are opposite of each other in the male and female samples. In the male sample, being married increases the probability of exiting unemployment for employment, as in OECD countries and in Palestine (Aranki and Daoud, 2005). In the female sample, being married reduces the probability of exit, unlike in the OECD countries. Apparently, for men being married implies family responsibilities inducing greater labour market attachment, but not for women. They may have higher opportunity cost of unemployment and thus search more intensively for a new job. Further, married women are likely to have non-wage income implying higher reservation wages. Thus, they are expected to have lower exit rates from unemployment to employment. The coefficient estimates for the regional dummy variables in the male sample indicate that all of the regions are not statistically significantly different from the Central Anatolia region, with exception of the Southeast Anatolia region where the probability of exiting unemployment for employment is significantly higher compared to Central Anatolia. This is somewhat surprising since Southeast Anatolia is one of the poorest regions of the country. This may be due to the fact that many people are out of work, not just unemployed in this region. This may be due to the fact that many people are out of work, not just unemployed in this region suggesting that it is more appropriate to study nonemployment rather than just unemployment in this region. Alternatively, the recent regional development program (GAP) of the government in this region may have been 
effective in producing greater employment opportunities. In the female sample the probability of exiting unemployment for employment in each region is not significantly different from that in Central Anatolia. In addition, the Black Sea region dummy becomes significant with a negative effect on the hazard when the broad definition of unemployment is used.

Next, the coefficient estimates of the dummy variables for different levels of education are examined. The base category includes individuals with no formal educational qualifications. In both the male and female samples all coefficient estimates are highly significant (with exception of the vocational high school coefficient for females) and positive, indicating that each level of education increases the probability of exiting unemployment for employment as compared to an individual with no formal educational qualifications. An F-test rejects the null hypothesis that the educational coefficients are the same across education levels. It is also noted that the effect of education increases with the level of education and that the effect is much larger for women than for men. The results are different with the broad definition of unemployment. In the male sample, the high school and vocational high school dummies are statistically significant with a negative sign indicating that graduates of general and vocational high schools have lower probabilities of exiting unemployment for employment compared to those with no formal educational qualifications. This may suggest that unlike individuals with no formal educational qualifications, the highly skilled unemployed may be more selective and may wait for a good job offer. It is also noteworthy that in the male sample, the exit rate from unemployment to employment is 
higher for vocational high school graduates than for high school graduates. Similar observations about vocational high school graduates are noted by Tansel (2002). For both men and women, two-year university graduates have significantly higher exit rates from unemployment for employment. In addition, in particular in the female sample, individuals with four or more years of university education have significantly higher exit probabilities from unemployment to employment than individuals with no formal educational qualifications, as is the case in developed countries. This may be due to either the higher opportunity cost of unemployment for the individuals with university education or better job-search skills, better information about labour market conditions and/or flexibility in accepting jobs below their qualifications.

The coefficient estimates on the age dummy variables indicate that men who are 45 and over have a lower probability of exiting unemployment for employment as compared to those who are in the base age group of 15-19, while the probabilities of exiting unemployment for employment in other age groups are not statistically different from that of the group aged 15-19. For females, the exit probability is lower at all ages compared to those aged 15-19. The effects are larger for women than for men in the older age groups. A lower exit rate at older ages is also found by Serneels (2001) in Ethiopia, and in the OECD countries. Low exit rates for elderly may be due to fewer job offers received since employers may regard their skills as obsolete and their productivity as lower due to an increased probability of health problems. The age effects in the male sample are similar for the broad and ILO definitions, while in the female sample with 
the broad definition the age effects become significant after age 35, and lose their significance in the group aged 55 and over.

The coefficient estimate of the local unemployment rate is statistically significant and negative in all samples, which implies that individuals in high-unemployment provinces have a lower probability of leaving unemployment for employment. The coefficient estimates are larger for females than for males, which indicates that local labour market conditions are more important for females. The exit rate from unemployment to employment for first-time job seeking men and women is significantly lower than for those who are non-first-timers. Again, these effects are larger for female first-timers than for male first-timers.

\section{Predicted Hazard Rates}

Table 7 presents the predicted probabilities of exiting from unemployment to employment in the first three months of unemployment under log-normal distribution ${ }^{\mathrm{xxvi}}$. The entries in the table are the predicted hazard rates for the indicated individuals at the median age group of 23-34 and various education levels with all other characteristics set at their mean values. The predicted hazard rate is lowest for individuals with no formal educational qualifications while it is highest for two-year university graduate men and women. The predicted probabilities of exiting unemployment to employment for vocational high school graduates are higher than for general high school graduates, for 
married men than for non-married men and for non-married women than for married women.

Table 7: The Predicted Hazard Rates for Individuals with Selected Characteristics

\begin{tabular}{|l|c|c|c|c|}
\hline & \multicolumn{2}{|c|}{ Male } & \multicolumn{2}{c|}{ Female } \\
\hline & Married & Non-Married & Married & Non-Married \\
\hline \multirow{2}{*}{$\begin{array}{l}\text { No Formal Educational } \\
\text { Qualification }\end{array}$} & & & & \\
Primary School & 24.05 & 18.38 & 9.69 & 12.22 \\
\cline { 2 - 5 } $\begin{array}{l}\text { Middle School } \\
\text { High School }\end{array}$ & 41.46 & 31.68 & 16.71 & 21.07 \\
\cline { 2 - 5 } $\begin{array}{l}\text { Voc. High School } \\
\text { Two-Year University }\end{array}$ & 36.72 & 28.06 & 14.80 & 18.67 \\
\cline { 2 - 5 } Four-Year Univ. and over & 34.12 & 26.07 & 13.76 & 17.34 \\
\cline { 2 - 5 } & 36.78 & 28.10 & 14.83 & 18.69 \\
\cline { 2 - 5 } & 52.21 & 39.89 & 21.05 & 26.54 \\
\hline
\end{tabular}

Source: Computed by the authors for the median age group, where all other variables are set at their mean values using the estimation results for the hazard model under log-normal distribution given in Table 6.

\section{Duration Dependence}

The baseline hazards by gender which are evaluated at the means of the variables for the log-normal distribution are shown in Figure 4. For men, the baseline hazard exhibits a declining trend about until the end of the second year (i.e. between 18 and 21 months) and then follows a slightly increasing trend. There are dips at the end of the second and third year in the baseline hazard for women, which initially seems constant followed by a slightly increasing trend, and is less pronounced than that of men. The Ushaped hazard implies that the probability of finding a job initially decreases and then increases as unemployment continues. Several lines of explanations can be provided for the initial negative duration dependence. It may be considered to be a result of employers perceiving unemployment duration as a signal about the potential productivity of the worker as the unemployed may lose valuable skills. Ceteris 
paribus, the declining exit rates by duration indicate that unemployment involves depreciation of skills and work habits, loss of motivation and discouragement, all of which are the so called scarring effect referred to in the literature. However, the initial downward slope does not have to imply the presence of scarring effects. At the beginning, those who find it easy to find a new job exit, whereas towards the

Figure 4: Shape of the Baseline Hazards under ILO Definition

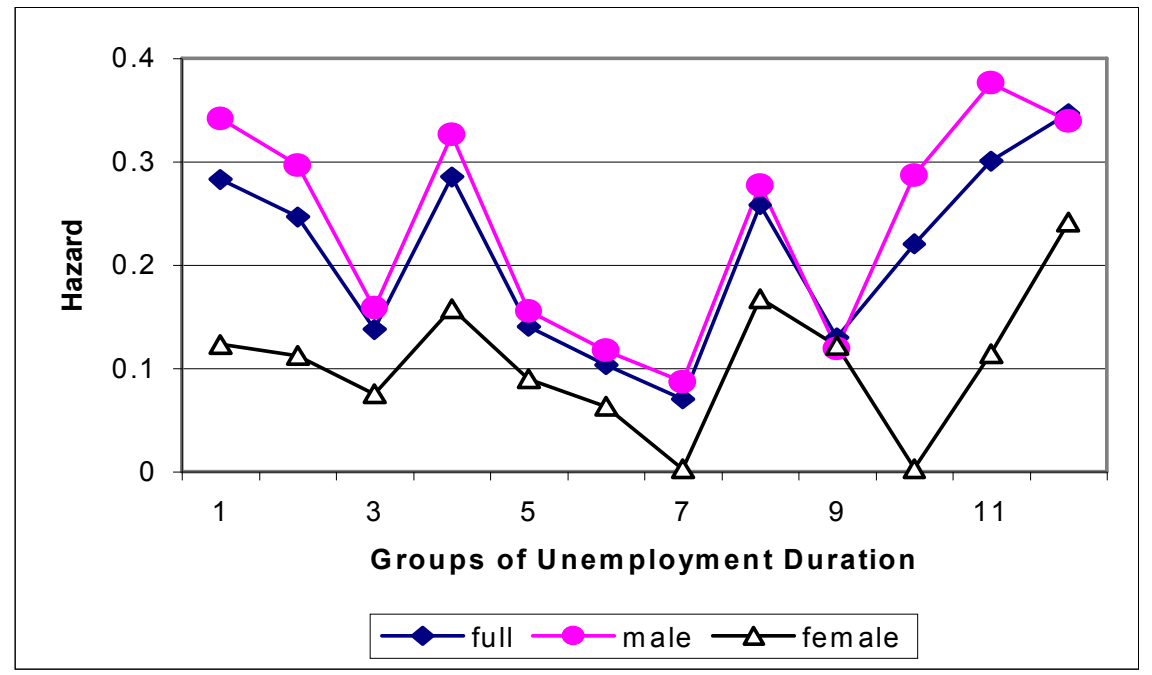

end those who run out of benefits and/or savings exit. Negative duration dependence is a well established result in the OECD countries. The subsequent positive duration dependence may be due to the presence of unemployment benefits or active labour market programs. It can also be generated simply by people running out of savings and/or family support. Such U-shaped duration dependence is also observed by Moffit (1985) for men in the US, by Ham and Rea (1987) for men in Canada and by van den Berg and Klaauw (2000) for men in France. Taşçı and Tansel (2005) find no 
duration dependence for youth in Turkey, i.e., the time spent in unemployment does not affect the probability of finding a job.

In the literature, the positive duration dependence is explained with the finiteness of the unemployment benefits, presence of active labour market policies for the long term unemployed, segmentation of the labour market and the business cycle effects. (Machin and Manning, 1999; Serneels, 2001). As remarked earlier, in Turkey, unemployment benefits are not relevant for the data period in this study. Similarly, active labour market policies were limited in scope and practiced only in some geographical regions. However, family support is widespread in Turkey and may play a role in explaining positive duration dependence. The labour market in Turkey could be considered segmented between the formal sector (with good/favourable jobs) and the informal sector (with bad/unfavourable jobs) (Tansel, 2000). Although Turkey does not have regulations guaranteeing public sector jobs to university graduates as is the case in some other developing countries, public sector jobs are favored by many (Tansel, 2005). Intuitively, non-negative duration dependence for both males and females may mean that they may wait in unemployment for good jobs (or queuing for a good job) while being supported by their family, and are unwilling to accept the bad jobs. This observation is supported by the anecdotal evidence that many young people wait in unemployment for a job that also provides social security benefits. This attitude seems to disappear after about the second year in unemployment.

\section{Summary and Conclusions}


This paper gives information on recent unemployment rates and examines the determinants of the probability of leaving unemployment for full-time employment in Turkey based on the 2000-2001 Household Labour Force Surveys of the Turkish Statistical Institute. The questions considered include the following. How do the individual, household and labour market characteristics affect the probability that a person will leave unemployment for employment? How does the probability that a person will leave unemployment vary with the duration of unemployment? The hazard rates were estimated for men and women separately using the ILO definition of unemployment. In performing the analysis, grouped duration methodology was employed, which is appropriate when the data are reported using larger time intervals than relevant for the underlying transitions themselves.

The probability of exiting unemployment for employment for women was found to be substantially lower than for men. However, the effects of the various covariates, with the exception of marital status, on the probability of leaving unemployment for employment were similar across men and women. For men, being married increased the probability of exiting unemployment, while for women being married decreased this probability. Further, although the urban unemployment rate was higher than the rural unemployment rate, living in an urban area did not have a significant effect on the probability of leaving unemployment for a job. The regional differences in the probability of leaving unemployment were mostly not statistically significant for men and women. Men and women who live in high-unemployment provinces had lower probabilities of leaving unemployment for a job. Furthermore, the probability of finding 
a job increased for both men and women with the level of education and decreased with age, as is also observed in the OECD countries. It is also noteworthy that in the male sample, the exit rate from unemployment to employment was higher for the vocational high school graduates than for the general high school graduates. This indicates the importance of vocational high schools as opposed to general high schools in combating unemployment in Turkey. The hazard rate was lower for first-time job-seekers than for those who were not first-time job- seekers, a finding similar to the findings for other developing countries. Although the low educated had lower unemployment rates, they had low exit rates from unemployment for employment. Conversely, the high exit rate for the educated is a result similar to that in developed countries. Findings also indicate slight U-shaped duration dependence for men while for women an initial flat portion is followed by an up-sloping tendency.

From a broader perspective, there are a number of indications that unemployment in Turkey is characterized by features of unemployment of developing as well as developed countries. The youth have high unemployment rates, but their probability of exit from unemployment to employment is high as well. This is a result similar to that in developed countries. The average duration of unemployment is lower than in other developing countries - a result similar to that in developed countries. Although the duration of unemployment is lower in urban areas, the incidence of unemployment is significantly higher there, as in other developing countries. Long-term unemployment is concentrated among the high skilled (high school and two-year university training) in contrast with OECD countries. Several results discussed suggest the existence of a 
queuing process for a good job. First, when using the broad definition for men, the coefficients on education are insignificant which suggests that the unemployed, who are mostly high skilled, prefer to wait for a good job rather than to search actively. Second, the broad definition of unemployment shows a constant hazard for both men and women. This too may suggest queuing. Although the first-time job-seekers constitute about thirty percent of the total number of unemployed in the sample, their hazard rate is lower. It is likely that first-time job-seekers are young and rely on family support while waiting for the right job opening. Those who had a job and lost it would be less likely to rely on family support. Furthermore, findings on women indicate that they may have a high shadow value of home production activities and thus a high reservation wage. It may also be an indication of discrimination against women in the labour market so that they receive fewer job offers. These findings point in the same direction as the broad conclusion for developing countries.

One of the policy suggestions of this paper would be provision of Active Labour Market Programs (ALMP) for the target groups consisting of individuals with low probability of leaving unemployment for employment. Several researchers, such as Kluve and Smidt (2002), are skeptical about the effectiveness of ALMPs. However, recent evidence shows that training programs are successful in allowing the unemployed to enter employment (Fitzenberg and Völter, 2007; Nivorozhkin and Nivorozhkin, 2007). Crepon et al. (2005) provide evidence on the effectiveness of the counseling of the unemployed. Only few active or passive labour market programs have been implemented in Turkey. These include training programs for labour displaced due to privatization 
(Tansel, 1998), apprenticeship training and programs directed at small businesses. Apprenticeship training programs have proved to increase employability of participants (Tansel and Ogawa, 2005). The analysis of this paper suggests that policymakers develop policies targeting women, especially married women, single men, individuals with low levels of education, individuals in the later years of their working lives, firsttime job-seekers and individuals living in high-unemployment provinces. Elderly individuals could be encouraged to invest into life-long training and individuals with low levels of education could be encouraged to invest in schooling and training to increase employability and productivity. First-time-job-seekers could be provided counseling in job-search skills. Individuals living in high unemployment provinces could be encouraged and subsidized to migrate to provinces where higher employment possibilities exist.

In view of the limited formal sector employment creation capacity of the Turkish economy, self-employment could be a solution to the unemployment problem even for the educated unemployed. Baumgartner and Caliendo (2007) provide evidence on the success and effectiveness of two recent ALMPs in Germany aimed at turning unemployment into self-employment. Indeed, self-employment could be a solution for the unemployed in Turkey as it is in other countries (Glocker and Steiner, 2007). The analysis results in this paper may be of use to policymakers in Turkey and other countries while facing the challenge of unemployment and developing policies to reduce it. 


\section{References}

Addison J. T. and Portugal P. (2002) 'Job Search Methods and Outcomes', Oxford Economic Papers, 54: 505-533.

Addison J. T. and Portugal P. (2003) 'Unemployment Duration: Competing and Defective Risks', Journal of Human Resources, 38(1): 156-191.

Alba R. A. (1998) 'Re-Employment Probabilities of Young Workers in Spain', Investigaciones Economicas, 22(2): 201-224.

Arellano F. A. (2005) 'Do Training Programmes Get the Unemployed Back to Work? A Look at the Spanish Experience; Working Paper No. 05-25, Department of Economics, Madrid: Universidad Carlos III.

Aranki T. N. and Daoud Y. (2006) 'Unemployment Duration in the Palestinian Territories: An Analysis of Personal and Political Factors', in T. N. Aranki, Wages Unemployment and Regional Differences, $\mathrm{PhD}$ Thesis, Orebro, Sweden: Orebro University.

Arulampalam W. (2001) 'Is Unemployment Really Scarring? Effects of Unemployment Experiences on Wages', The Economic Journal, 111: F585-F606.

Arulampalam W. and Stewart M. B. (1995) 'The Determinants of Individual Unemployment Durations in an Era of High Unemployment', The Economic Journal, 105: 321-332.

Baumgartner H. J. and Caliendo M. (2007) 'Turning Unemployment into SelfEmployment: Effectiveness and Efficiency of Two Start-Up Programmes', Institute for Study of Labor (IZA), Discussion Paper No. 2660, Bonn: IZA.

Bover O. and Gomez R. (2004) 'Another Look at Unemployment Duration: Exit to a Permanent vs. a Temporary Job’, Investigaciones Económicas, 28(2): 285-314.

Böheim R. (1999) 'Austrian Unemployment Durations', Institute for Social and Economic Research, Discussion Paper No. 1999-14, Essex, Colchester: University of Essex. 
Böheim R. and Taylor M. P. (2000) 'Unemployment Duration and Exit States in Britain', Institute for Social and Economic Research, Discussion Paper No. 2000-, Essex, Colchester: University of Essex.

Brandolini A., Cipollone P. and Viviano E. (2006) 'Does the ILO Definition Capture All Unemployment?', Journal of the European Economic Association, 4(1): 153-179.

Bulutay T. (1995) Employment, Unemployment and Wages in Turkey, Ankara: State Institute of Statistics and International Labor Office.

Byrne, D. and Strobl E. (2004) 'Defining Unemployment in Developing Countries: Evidence from Trinidad and Tobago', Journal of Development Economics, 73: 465-476.

Carling K., Edin P., A. Harkman A. and Holmlund B. (1996) 'Unemployment Duration, Unemployment Benefits and Labor Market Programs in Sweden', Journal of Public Economics, 59(3): 313-334.

Carrol N. (2006) 'Explaining Unemployment Duration in Australia', The Economic Record, 82(258): 298-314.

Clark A. E. (2006) 'A Note on Unhappiness and Unemployment Duration', Appplied Economics Quarterly, 52(4): 291-308.

Clark A. E. and Oswald A. J. (1994) 'Unhappiness and Unemployment', Economic Journal, 104: 648-659.

Clark K. B. and Summers L. H. (1979) 'Labor Market Dynamics and Unemployment: A Reconsideration', Brookings Papers on Economic Activity, 1979(1): 13-72.

Clark K. B. and Summers L. H. (1982) 'The Dynamics of Youth Unemployment' in The Youth Labor Market Problems: Its Nature, Causes and Consequences, R. Freeman and D. Wise (ed.), Chicago: University of Chicago Press for National Bureau of Economic Research. (pp. 199-234).

Cooper D., McCausland D. W. and Theodossiou I. (2007) 'Is Unemployment Harmful to Health? Evidence from Britain, Centre for European Labour Market Research, Discussion Paper No. 2007-12, Aberdeen: University of Aberdeen Business School.

Crépon B., Dejemeppe M. and Gurgand M. (2005) 'Counseling the Unemployed: Does It Lower Unemployment Duration and Recurrence?', Institute for Study of Labor (IZA). Discussion Paper No: 1796, Bonn: IZA. 
Darity W. Jr. and Goldsmith, A. H. (1996) 'Social Psychology, Unemployment, and Macro-economics', Journal of Economic Perspectives, 10: 121-40.

Dendir S. (2006) 'Unemployment Duration in Poor Developing Economies: Evidence From Urban Ethiopia', The Journal of Developing Areas, 40(1): 181-201.

Devine T. J. and Kiefer N. M. (1991) Empirical Labor Economics, Oxford: Oxford University Press.

Dickens W.T. and Lang K. (2006) 'An Analysis of the Nature of Unemployment in Sri Lanka', Journal of Development Studies, 31: 620-36.

Earle J. S. and Pauma C. (1996) 'Incidence and Duration of Unemployment in Romania', European Economic Review, 40(3-5): 829-837.

Ercan H. and Tansel A. (2007) 'How to Approach the Challenge of Reconciling Labor Flexibility with Job Security and Social Cohesion in Turkey', in Reconciling Labour Flexibility with Social Cohesion, Trends in Social Cohesion, No: 17., Strasbourg: Council of Europe. (pp: 179-205).

Eggers A., Gaddy C. and Graham C. (2006) 'Well-Being and Unemployment in Russia in the 1990s: Can Society's Suffering be Individual's Solace?', Journal of SocioEconomics, 35: 209-242.

Fajnzylber P., Lederman D. and Loayza N. (1998) Determinants of Crime Rates in Latin America and the World: An Empirical Assessment, Washington DC: The World Bank.

Fitzenberger B. and Wilke R. A. (2007) 'New Insights on Unemployment Duration and Post Unemployment Earnings in Germany: Censored Box-Cox Quantile Regression at work', Institute for the Study of Labor (IZA), Discussion Paper No. 2609, Bonn: IZA.

Fitzenberger B. and Völter R. (2007) 'Long-Run Effects of Training Programs for the Unemployed in East Germany', Institute for the Study of Labor (IZA), Discussion Paper, No. 2630 Bonn: IZA.

Flinn C. J. and Heckman J. J. (1983) 'Are unemployment and out of the Labor Force Behaviorally Distinct Labor Force States?' Journal of Labor Economics, 1: 28-42.

Foley M. C. (1997) 'Labor Market Dynamics in Russia', Economic Growth Center. Discussion Paper no. 780, New Haven: Yale University. 
Fougère D., Kramaz F. and Pouget J. (2009) 'Youth Unemployment and Crime in France', Journal of the European Economic Association, 7(5): 909-938.

Frey B. S. and Stutzer A. (2000) 'Happiness, Economy and Institutions', Economic Journal, 110: 918-938.

Garrido L. and Toharia L. (2004) 'What does it take to be (counted as) unemployed: The case of Spain', Labour Economics, 11(4): 507-523.

Glewwe P. (1987) 'Unemployment in Developing Countries: Economist's Models in Light of Evidence from Sri Lanka', International Economic Journal, 1(4): 1-17.

Glocker D. and Steiner V. (2007) 'Self-Employment: A Way to End Unemployment? Empirical Evidence from German Pseudo-Panel Data', Institute for the Study of Labor (IZA) Discussion Paper, No. 2561, Bonn: IZA.

Goldsmith A. H., Veum J. R. and Darity W. Jr. (1996) 'The Impact of Labor Force History on Self-esteem and its Component Parts, Anxiety, Alienation, and Depression', Journal of Economic Psychology, 17: 183-230.

Gonzalo M. T. (1998) 'Job Exit of Men: New Job Destination versus Unemployment Destination', Applied Economics, 30: 1231-1238.

Gould, E. D., Weinberg A. and Mustard D. B. (2002) 'Crime Rates and Local Market Opportunities in the United States: 1979-1997', The Review of Economics and Statistics, 84(1): 45-61.

Gönül F. (1992) 'New Evidence on Whether Unemployment and out of the Labor Force are Distinct States', Journal of Human Resources, 27(2): 329-361.

Grogan L. and van den Berg G. J. (2001) 'The Duration of Unemployment in Russia', Journal of Population Economics, 14(3): 549-568.

Guo G. (1993) 'Event History Analysis for Left-Truncated Data', Sociological Methodology, 23: 217-243.

Hardin J. and Hilbe J. (2001) Generalized Linear Models and Extensions, Texas: Stata Press. 
Ham J. C. and Rea. A. S. (1987) 'Unemployment Insurance and Male Unemployment Duration in Canada', Journal of Labor Economics, 5: 325-353.

Hirschman C. (1982) 'Unemployment among Urban Youth in Peninsular Malaysia, 1970: A Multivariate Analysis of Individual and Structural Effects', Economic Development and Cultural Change 30(2): 391-412.

Huang C. C., Laing D. and Wang P. (2004) 'Crime and Poverty: A Search-Theoretic Approach', International Economic Review, 45(3): 909-938.

Hunt J. (1995) 'The Effect of Unemployment Compensation on Unemployment Duration in Germany', Journal of Labor Economics, 13: 88-120.

Hussmanns R., Mehran F. and Vijay V. (1990) Surveys on Economically Active Population: An ILO Manual on Concepts and Methods, International Labor Office (ILO), Geneva: ILO.

Jackson P.R. and Warr P.B. (1984) 'Unemployment and Psychological Ill-health: The Moderating Role of Duration and Age', Psychological Medicine, 14(3): 605614.

Jenkins S. P. (1995) 'Easy Estimation Methods for Discrete-time Duration Models', Oxford Bulletin of Economics and Statistics, 57(1): 129-138.

Jenkins S. P. and García-Serrano C. (2004) 'Re-employment Probabilities for Spanish Men: What Role does the Unemployment Benefit System Play?' Oxford Bulletin of Economics and Statistics, 66(2): 239-261.

Jones S. R. G. and Riddell W. C. (1999) 'The Measurement of Unemployment: An Empirical Approach', Econometrica, 67(1): 147-161.

Jones S. R. G. and Riddell W. C. (2006) 'Unemployment and Non-Employment: Heterogeneities in Labour Market States', The Review of Economics and Statistics, 88(2): 314-323.

Katz L. F. and Meyer B. D. (1990) 'The Impact of the Potential Duration of Unemployment Benefits on the Duration of Unemployment', Journal of Public Economics, 41: 45-72.

Kenneth B., Lagos R. and Wright R. (2004) 'An On-The-Job Search Model of Crime, Inequality, and Unemployment', International Economic Review, 45(3): 681-706. 
Klein J. P. and Moeschberger M. L. (1997) Survival Analysis: Techniques for Censored and Truncated Data, New York: Springer-Verlag.

Kluve J. and Schmidt C. (2002) 'Can Training and Employment Subsidies Combat European Unemployment?’, Economic Policy, 35: 411-448.

Kiefer N. M. (1988) 'Analysis of Grouped duration Data', Contemporary Mathematics, 80: 107-139.

Kingdon G. and Knight J. (2000) 'Are Searching and Non-Searching Unemployment Distinct States When Unemployment is High? The Case of South Africa', The Center of African Economics Working Paper Series, No: 2000/2, Oxford: University of Oxford.

Knight J. and Li S. (2006) 'Unemployment Duration and Earnings of Re-employed Workers in Urban China', China Economic Review, 17: 103-119.

Kupets O. (2006) 'Determinants of Unemployment Duration in Ukraine', Journal of Comparative Economics, 34: 228-247.

Lancaster T. (1990) The Econometric Analysis of Transition Data, Cambridge: Cambridge University Press.

Lewis G. and Sloggett A. (1998) 'Suicide, Deprivation, and Unemployment: Record Linkage Study’, British Medical Journal, 317: 1283-1286.

Lubyova M. and van Ours J. C. (1997) 'Unemployment Dynamics and the Restructuring of the Slovak Unemployment Benefit System', European Economic Review, 41(3-5): 925-934.

Lynch L. M. (1983) 'Job Search and Youth Unemployment', Oxford Economic Papers, 35: 271-282.

Lynch L. M. (1989) 'The Youth Labour Market in the Eighties: Determinants of Reemployment Probabilities for Young Men and Women', The Review of Economics and Statistics, 71: 37-45.

Machin S. and Manning C. (1999) 'The Causes and Consequences of Long-term Unemployment in Europe', in Handbook of Labor Economics, 3c, A. Orley and D. Card (eds.), Amsterdam: North Holland, (pp: 3085-3139). 
Manning C. and Junankar P. N. (1998) 'Choosy Youth or Unwanted Youth? A Survey of Unemployment', Bulletin of Indonesian Economic Studies, 34(1): 55-93.

Meyer B. D. (1990) 'Unemployment Insurance and Unemployment Spells', Econometrica, 58(4): 757-782.

Meghir C., Ioannides Y. and Pissarides C. (1989) 'Female Participation and Male Unemployment Duration in Greece: Evidence from the Labor Force Survey', European Economic Review, 33: 95-406.

Moffit R. (1985) 'Unemployment Insurance and the Distribution of Unemployment Spells', Journal of Econometrics, 28: 85-101.

Moon W. S. (2005) 'Distinguishing Unemployment from Out of the Labor Force', Department of Economics, Rochester, NY: University of Rochester.

Murphy G. C. and Athanasou, J. A. (1999) 'The Effect of Unemployment on Mental Health', Journal of Occupational and Organizational Psychology, 72: 83-99.

Narendranathan W. and Stewart M. B. (1993) 'Modelling the Probability of Leaving Unemployment: Competing Risks Models with Flexible Baseline Hazards', Applied Statistics, 40(1): 63-83.

Nickell S. (1985) 'Hourly earnings in the US: Another look at Unionization Schooling, Sickness and Unemployment using PSID Data', Journal of Labor Economics, 3: 38-69.

Nivorozhkin A. and Nivorozhkin E. (2007) 'Do Government Sponsored Vocational Training Programmes Help the Unemployed Find Jobs? Evidence from Russia', Applied Economics Letters, 14: 5-10.

OECD (2006) Employment Outlook Edition: Boosting Jobs and Incomes, Statistical Annex, url Link: http://www.oecd.org/dataoecd/53/15/36900060.pdf.

Özel H. and Mehran F. (1992) 'Assessment of Employment and Unemployment', in Proceedings of Seminar on Employment, Unemployment and Wages in Turkey, T. Bulutay (ed.), Ankara: State Institute of Statistics.

Pellizzari M. (2005) 'Unemployment Duration and the Interactions between Unemployment Insurance and Social Assistance', Labor Economics, 13(6): 773-798. 
Platt S. (1984) 'Unemployment and Suicidal Behavior: A rewiev of the Literature', Social Science and Medicine, 19(2): 93-115.

Portugal P. and Addison J. T. (2008) 'Six Ways to Leaving Unemployment', Scottish Journal of Political Economy, 55(4): 393-419.

Powdthavee N. (2006) 'Are There Regional Variations in the Psychological Cost of Unemployment in South Africa?', Social Indicators Research, 80(3): 629-652.

Prentice, R. and Gloeckler L. (1978) 'Regression Analysis of Grouped Survival Data with Application to Breast Cancer Data', Biometrics, 34: 57-67.

Rama M. (1998) 'How Bad is Unemployment in Tunisia? Assessing Labor Market Efficiency in a Developing Country', World Bank Research Observer, 13(1): 59-78.

Rama, M. (2003) 'The Sri Lankan Unemployment Problem Revisited', Review of Development Economics, 7: 510-525.

Reyher L., Koller M. and Spitznagel E. (1980), Employment Policy Alternatives to Unemployment in the Federal Republic of Germany - Issues, Effects on the Labour Market and Costs, London: Anglo-German Foundation for the Study of Industrial Society.

Ruhm, C. J. (1991) 'Are Workers Permanently Scarred by Job Displacements', American Economic Review, 81: 319-24.

Sabot, R. H. (1982) 'Conclusion: Some Themes and Unresolved Issues', in Migration and the Labor Market in Developing Countries, R. H. Sabot (ed.), Boulder Colorado: Westview Press, (pp. 229-241).

Schweitzer M. (2003) 'Ready, Willing, and Able? Measuring Labour Availability in the UK.', Cleveland: Federal Reserve Bank of Cleveland Working Paper No. 03-03.

Serneels, P. (2001) 'Unemployment Duration in Urban Ethiopia', Discussion Paper, Center for the Study of African Economies, Oxford: Oxford University.

Serneels, P. (2007) 'The Nature of Unemployment among Young Men in Urban Ethiopia', Review of Development Economics, 11(1): 170-186. 
Sinclair, P. (1987) Unemployment, Economic Theory and Evidence, Oxford: Basil Blackwell Inc.

State Institute of Statistics (SIS) (2001a) Household Labor Force Survey Results 2000, October 2001, Ankara: State Institute of Statistics.

State Institute of Statistics (SIS) (2001b) Hanehalkı Issgücü Anketi: Kavramlar ve Yöntemler (Household Labor Force Survey: Concepts and Methods. Ankara: State Institute of Statistics, Publication No.2484.

Steiner, V. (2001) 'Unemployment Persistence in the West German Labor Market: Negative Duration Dependence or Sorting', Oxford Bulletin of Economics and Statistics, 63: 91-114.

Şahin, H. and Kizllırmak, A. B. (2007) 'Determinants of Duration of Unemployment Insurance

Benefits in Turkey', Applied Economics Letters, 14(8): 611-615.

Sueyoshi, G. T (1995) 'A Class of Binary Response Models for Grouped Duration Data', Journal of Applied Econometrics, 10(4): 411-431.

Suryadarma D., Suryahadi A. and Sumarto S. (2007) 'Measuring Unemployment in Developing Countries: The Case of Indonesia', Labour: Review of Labor Economics and Industrial Relations, 21(3): 541-562.

Şenses, F. (1994) 'Labor Market Response to Structural Adjustment and Institutional Pressures: The Turkish Case', METU Studies in Development, 21(3): 405-448.

Tanjo, J. (1990) 'Opportunities, Aspirations, and Urban Unemployment of Youth: The Case of Colombia', Economic Development and Cultural Change, 38(4): 733-61.

Tansel A. (1998) 'Workers Displaced Due to Privatization in Turkey: Before and After Displacement', METU Studies in Development, 25(4): 625-647.

Tansel A. (2000) 'Formal and Informal Sector Choice of Wage-Earners and Their Wages in Turkey', in Informal Sector I., T. Bulutay (ed.). Ankara: State Institute of Statistics, (pp: 125-146).

Tansel A. (2001) 'Female Labor Force Participation and Economic Development in Turkey: Time-Series Evidence and Cross-Province Estimates', in Employment of Women, T. Bulutay (ed.). Ankara: State Institute of Statistics, (pp: 111-151). 
Tansel A. (2002) 'General versus Vocational High Schools and Labor Market Outcomes in Turkey', in Human Capital: Population Economics in the Middle East, I. Sirageldin (ed.), Cairo, Egypt: Economic Research Forum and American University of Cairo Press, (pp: 258-272).

Tansel A. (2005) 'Public-Private Employment Choice, Wage Differentials and Gender in Turkey', Economic Development and Cultural Change, 53(1): 453-477.

Tansel A. and Ogawa K. (2005) 'The Effects of Apprenticeship Training Scheme on Employment Probability in Turkey', Department of Economics, Ankara: Middle East Technical University.

Tansel A. and Taşçı H. M. (2004) 'Determinants of Unemployment Duration for Men and Women in Turkey', Institute for Study of Labor (IZA), Discussion Paper No: 1258, Bonn: IZA.

Taşçı H. M. (2005) Essays on Unemployment in Turkey, PhD Thesis, Department of Economics, Ankara: Middle East Technical University.

Taşçı H. M. and Tansel, A. (2005) 'Youth Unemployment Duration in Turkey', METU Studies in Development, Special Issue in Honor of Merih Celasun, 32(2): 517-545.

Tunalı İ. and Assaad R. (1992) 'Market Structure and Spells of Employment and Unemployment: Evidence from the Construction Sector in Egypt', Journal of Applied Econometrics, 7: 339-367.

Tunalı İ. and Baltac1 R. (2003) 'Attrition in the HLFS Panel, 2000-2002', Unpublished Manuscript Presented at the $7^{\text {th }}$ METU International Conference in Economics in Ankara in September 2003, under the title 'Labor Market Dynamics Based on the HLFS Panel, 2000-2002'.

Tunali İ., Ercan H., Başlevent C. and Öztürk O. D. (2004) Background Study on Labor Market and Employment in Turkey, Torino, Italy: European Training Foundation.

Turkish Statistical Institute (Turkstat) (2004) Website of TUIK, url: http://www.tuik.gov.tr.

Turkish Statistical Institute (Turkstat) (2006) Household Labor Force Survey Results, March 2006, News Bulletin, url: http://www.tuik.gov.tr . 
Udall A. T. and Sinclair S. (1982) 'The Luxury Unemployment Hypothesis: A review of Recent Evidence', World Development, 10: 49-62.

van den Berg G. J. (1990) 'Non-stationarity in job Search Theory', Review of Economic Studies, 57: 255-277.

\author{
van den Berg G. J. and van Ours J. C. (1999) 'Duration Dependence and \\ Heterogeneity in French Youth Unemployment Durations', Journal of Population \\ Economics, 12(2): 273-285.
}

\title{
Winkelmann L. and Winkelmann R. (1998) 'Why are the Unemployed so Unhappy: Evidence from Panel Data', Economica, 65: 1-15. Wooldridge J. M. (2002) Econometric Analysis of Cross Section and Panel Data, Cambridge: MIT Press.
}

i By TUIK's definition underemployed includes the involuntary part-time workers who are individuals working less than 40 hours but are able to work more and the individuals who do not receive adequate income in their current employment or their current job does not match their skills (SIS, $2001 \mathrm{a}, \mathrm{b}$ ).

ii A location is defined as urban if its population is over 20000 .

iii We addressed this problem by performing three kinds of robustness analysis. In the first approach, we dropped from the sample those who are not re-interviewed and re-estimated the models. In the second approach, we included in the sample those for whom there is repeated data and re-estimated the models. In the third approach we included only the fresh samples which are brought in at each round of the survey and re-estimated the models. By definition fresh samples are not influenced by attrition (Tunali and Baltac1, 2004). In each of these cases the estimation results did not differ substantially from the case where total number of observations are used. Further discussion of these results is reported in Tansel and Taşçı (2004).

iv The unemployed individual is also asked if he/she registered at the Job-Placement Office, his/her current job search strategies and the sector at which he/she is looking for a job. The registration at the Job-Placement Office is rather low. Only 7.1 per cent of ILO unemployed individuals are registered at the Office. The same number for the broad definition was about 6.4 percent.

$\mathrm{v}$ The retrospective question could be affected by recall error with individuals inaccurately remembering for how long they have been unemployed. The extent of recall error could also vary between individuals depending on, for example, the duration of the unemployment spell as well as individual characteristics which may bias the results of interest. However, there is no other external (i.e. administrative) data set available with which to compare these calculated durations.

vi Sampling plan of the HLFS, in general, allows us to follow $50 \%$ percent of the survey respondents in the subsequent quarters and years. Further, it allows us to follow approximately $25 \%$ of the of 2000(q1) survey respondents "four" times [in 2000 (q2), 2001(q1) and 2001(q2). Moreover, another 25\% of the respondents of the 2000(q1) survey are observed "three" times [in 2000 (q4), and 2001(q1) in our data set. [For the detailed discussion see Tunali and Baltaci (2004) and (SIS 2001b). Thus, we have minimum of 2587 individuals who are observed minimum of 2-times, under ILO definition of unemployment. Among these individuals 1144 (of 2587) individuals visited 3-times and 305 visited 4-times Of course there are also some individuals who are only one data point (i.e. only right censored observation), the are 2247 number of individuals in total, under ILO definition of unemployment. The numbers corresponding to broad definition can be obtained from the authors upon request

vii Suppose that an individual found a job in the second quarter of 2000, who were observed as unemployed (with known elapsed duration unemployment) in the first quarter of 2000 . If this is the case one needs to use some extra question about when s/he found a job, however, the HLFS survey does not ask this to this respondent. Therefore, it is not possible to observe the exact time when this individual found a job. Thus the unemployment duration data for this individual will be "left-truncated with known starting time" (Guo, 1993, for this definition) and "interval censored". In our data set 560 individuals have two-spells of unemployment and 57 individuals have three-spells of unemployment, under ILO definition of unemployment. The numbers with the broad definition is 
available from the authors upon request. In our analysis we used one data point for each individuals. The results with the multiplespell data as mentioned in endnote 4 is available from the authors upon request where we consider them as separate observations. viii In order to deal with interval-censored observations we initially applied some rules of thumb that are commonly used in the literature (see for example, Grogan and van den Berg, 2001 and Foley, 1997). These rules included the assumptions of zero time spent in unemployment, 50 percent time spent in unemployment, all time spent in unemployment and the random time spent in unemployment. We carried out extensive sensitivity analysis by experimenting with these rules in the context of continuous time framework. Specifically in the continuous time framework we estimated exponential, Weibull, log-logistic and log-normal models. Best results are obtained with the log-normal model according to Akaike's Information Criterion. These results are available from the authors upon request. Later on, we switched to the grouped duration analysis recognizing the discrete nature of the data. Here we take the interval-censoring explicitly into account. We consider the groups narrow enough to prevent information loss but wide enough to include each unemployment spell's true durations. See section 4 for more on using grouped duration analysis.

ix One may wonder whether it is possible for respondents to declare themselves unemployed but get income from informal work. According to the questionnaire design it is highly unlikely for this to happen. Because, in the survey, people economically active during the reference period for at least one hour as a regular employee, casual employee, employer, self employed or unpaid family worker are considered employed. This employment includes formal and informal types. In fact, there are several control questions to decide if the people are employed and derive income from formal or informal source alike.

$x$ The broad measure of unemployment extends the ILO definition in the sense that we now include those who did not use one of the search channels during the past three months but may have used earlier and available to start a job within 15 days. For this reason, the question "how long have you been seeking a job?" is answered by every unemployed who stated that they have been looking for a job.

xi The issue of whether unemployment and out of the labour force are behaviorally distinct states is addressed by several researchers such as Flinn and Heckman (1983), Gönül (1992), Jones and Riddel (1999 and 2006), Moon (2005) and Kupets (2006). The empirical evidence on this issue is mixed. Kupets (p.11) draws attention to the occurrence of spurious events resulting from classification error when analyzing unemployment duration.

xii Before estimation, we re-organized the data in person-period form depending on the choice of interval difference or grouping. The time axis is divided into intervals such that they contain each spell's reported duration. We assigned three-month intervals until the end of the second year, six-month intervals until the end of the third year and twelve-month intervals until the end of the fourth year. The final group includes the unemployment durations of more than four years. This gives a total of twelve grouping intervals. In this grouping we reached from 4,834 $(6,983)$ individual observations to 11,544 person period observations under ILO (broad) definition. Experimenting with alternative groupings did not change the overall estimation results of the models.

xiii See Prentice and Gloeckler (1978), Guo (1993) and Sueyoshi (1995) for a derivation of the likelihood function.

xiv We also examined the transition from unemployment to out-of-labour force. A discussion of these results is provided in endnote 22. Further, it was not possible to analyze the transitions from unemployment to employment by making full-time and part-time distinction due to data limitations. The 2000 and 2001 HLFS questionnaire design indirectly allowed this distinction with the question number 29 (see SIS, 2001b). In our sample there is only one individual who reported working part-time since s/he could not find a full-time job. Part-time employment is not prevalent in Turkey. In 2005 only 1.56 percent of the wage earners were parttime employed. The transitions from unemployment to other forms of employment are also not considered due to data limitations. The HLFS allowed distinguishing among regular employment, causal employment, family employment, employer, self-employment and family worker. In our sample, 72.0 percent of females report finding a regular job and the percentage of those who found other forms of employment are very small. Similarly, among the males, 36 percent took regular employment, 35 percent became casual employee and 17 percent became self-employed.

The statistics in this regard in 2005 in Turkey are as follows. The most prevalent form of employment in urban areas is wage earning for both men and women with 63.04 and 72.07 percent, respectively, while self-employment is 18.06 percent for men and 9.42 percent for women. In rural areas self-employment is the most common form of employment for men with 45.2 percent while rural women are mostly unpaid family workers with 66.8 percent. (TUIK, 2006). 
xv We also estimated our models using the approach developed by Guo (1993) under same distributions. The estimation results are mostly similar to those provided in this paper, and, are also available from the authors upon request.

xvi The plots of the survivor and hazard functions and the testing results for the equality of survivor functions under "broad" definition of unemployment are similar to those under "ILO" definition. Therefore, in this part, we provide and discuss the results under the ILO definition only. For the results under the broad definition of unemployment refer to Tansel and Taşçı (2004).

xvii We also considered the timing of the unemployment spell. This could indeed be important given the severe financial and economic crises the Turkish economy suffered in November 2000 and February 2001. Therefore we performed a robustness analysis by splitting the sample into two. One sample referred to the no-crisis quarters of 2000 and the other sample referred to the crisis quarters of 2000 and 2001. The results from the two samples were qualitatively similar. They are available from the authors upon request. The reason for this finding is that, the year 2000 was already a year of stagnant economy and we use data only for the first two quarters of 2001 during which the full effect of the February 2001 crisis on unemployment was not felt. The quarterly unemployment rates for the four quarters of 2000 were 8.3, 6.2, 5.6, and 6.2 respectively. The same rates for the four quarters of 2001 were 8.5, 6.7, 7.8 and 10.4. Therefore, the unemployment effect of the crisis was felt only during the latter part of the 2001 and continued in 2002 and 2003.

xviii Testing results for the proportionality assumption appear in Tansel and Taşçı (2004).

xix The estimation results under PHM and log-logistic specifications are given in Tansel and Taş̧̧ (2004).

$\mathrm{xx}$ The effect of disregarding the unobserved heterogeneity is like that of the omitted variables in the ordinary least squares. In particular, the estimate of the duration dependence in the hazard becomes inconsistent by the omission of unobserved heterogeneity. For a detailed discussion see Devine and Kiefer (1991) and Wooldridge (2002).

xxi For the similar observations see Arulampalam and Stewart (1995), Carling et al. (1996), Foley (1997), Böheim (1999), Böheim and Taylor (2000), Grogan and van den Berg (2001), Jenkins and Serrano (2004), Arellano (2005), Dendir (2006) and Kupets (2006).

xxii The covariates used in the analyses are measured at time of the survey.

xxiii We note that the HLFSs of 2000 and 2001 did not collect information on earnings or unearned incomes of the individuals. Therefore, such information could not be included in our analysis. Recently, several researchers such as Ham and Rea (1987), Katz and Meyer (1990), Hunt (1995) and Pellizari (2005) investigated the effect of unemployment insurance on unemployment duration. This also could not be analyzed in our study since the unemployment benefit system was instituted in Turkey on June 1, 2000 and no benefits were being paid when the surveys were conducted in 2000 and 2001. Our earlier estimations of the hazard models included dummy variables for various occupations among the covariates. Interested readers can find such specifications in Tansel and Taşçı (2004).

xxiv We also analyzed the transitions from unemployment to the out-of-the-labour-force by treating the transitions to the other labour market states as right censored. These results are not reported for brevity but are available from the authors upon request. The main conclusions are as follows. Women in particular married women have higher probabilities of exiting to out-of-the-labour-force from unemployment with both the ILO and the broad definitions of unemployment. In contrast, men in particular the married men have lower probabilities of exiting to out-of-the-labour-force from unemployment. There are no significant regional differences for men while for women living in the Aegean region decreases the probability of exiting to out-of-the-labour-force. Different levels of education did not significantly influence the probability of exiting to out-of-the-labour-force for men. For women this probability is lower at the university level of education under the broad definition of unemployment. The age effects have a U-shape as expected for both men and women with both definitions of unemployment implying that the elderly exit to out-of-the-labour-force with greater probability. First-time job-seeking did not significantly influence the probability of exiting to out-of-the-labour-force for both men and women. The shape of the baseline hazard was more or less a horizontal line with no-clear indication of an increase or decrease in the hazard rate with both definitions of unemployment.

xxv The estimates under the broad definition are available in Tansel and Taşçı (2004).

xxvi The results under PHM and log-logistic specifications are available from the authors upon request. 